\title{
Nickel and Palladium Complexes with New Phosphinito-Imine Ligands and Their Application as Ethylene Oligomerization Catalysts.
}

Laura Ortiz de la Tabla, Inmaculada Matas, Pilar Palma, Eleuterio Álvarez and Juan Cámpora*

Instituto de Investigaciones Químicas (IIQ), Consejo Superior de Investigaciones Científicas - Universidad de Sevilla. Avda. Américo Vespucio 49, 41092 Sevilla, Spain. E-mail: campora@iiq.csic.es

Summary: Phosphinito-imines, a new class of $P, N$ donors, are readily generated by reaction of bulky arylamide anions $\left[R^{2}\right.$ CONArJ $\left(R^{2}=\right.$ Me or $\left.t-B u ; A r=2,6-i-P_{2} C_{6} H_{4}\right)$ with chlorophosphines $C I P\left(R^{1}\right)_{2}$. In solution, free phosphinito-imines exist in equilibrium with the corresponding amidophosphine tautomers, containing a nitrogen-bound $P\left(R^{1}\right)_{2}$ group. However, reacting the tautomer mixtures with metal precursor complexes, such as $\mathrm{NiBr}_{2}(\mathrm{dme})$ or $\mathrm{PdCl}_{2}(\mathrm{cod})$, selectively affords stable phosphinito-imine complexes $M X_{2}(P-N)(M=N i, P d)$ in excellent yields. These complexes are diamagnetic and exhibit square planar structures in the solid state, but in solution the Ni derivatives exchange with a small amount of the corresponding high-spin tetrahedral isomers. On treatment with MMAO or DEAC, NiX $(P-N)$ complexes become active ethylene oligomerization catalysts, affording mainly butenes along with smaller amounts of hexenes and octenes. The activity and the selectivity of these catalysts depend on the structure of the phosphinito-imine ligand and the co-catalyst used. When activated with DEAC, complexes containing the $P(i-$ $\mathrm{Pr})_{2}$ moiety are extremely active, achieving TOFs over $10^{6} \mathrm{~mol}_{2} \mathrm{H}_{4} / \mathrm{mol} \mathrm{Ni} \cdot h$ and high selectivity for butenes.

\section{Introduction}

Hybrid ligands containing hard and soft donor atoms have been widely studied and applied in organometallic chemistry and homogeneous catalysis due to the structural diversity of their complexes and their ability to impart unusual chemical reactivity. ${ }^{1-5}$ Ligands containing P,O, P,N or N,O donor sets introduce significant differentiation at the trans positions in the coordination sphere of a metal center, which has important consequences for the catalytic activity of such complexes. ${ }^{2,6-10}$ Many nickel(II) complexes containing hybrid ligands have been reported to catalyze ethylene oligomerization, by favoring chain transfer over propagation during the catalytic cycle. ${ }^{11-13}$ A reference for these are the Shell Higher Olefin Process (SHOP) catalysts. These are based on Ni complexes with anionic P,O donors and produce Schulz-Flory mixtures of oligomers with high selectivity for $\alpha$-olefins. ${ }^{14,15}$ Modification of the P,O ligands system leads to very significant changes on the catalyst selectivity ${ }^{16}$ that can be shifted from ethylene oligomerization to polymerization, in some cases with activities comparable to metallocene derivatives. ${ }^{17}$ Despite the important developments achieved in this area, metal catalysts producing short-chain $\alpha$-olefins with narrow Schulz-Flory distributions are still main targets. ${ }^{18-20}$

Nickel and palladium catalysts containing $\mathrm{P}, \mathrm{N}$ ligands have received much attention in the context of ethylene oligomerization ${ }^{8,10,21-35}$ or polymerization. ${ }^{28.29,35}$ In general, the presence of a phosphorus donor enhances the stability of the complexes, while the imine fragment can be used for tuning the activity and selectivity of the catalyst. For instance, heterocyclic fragments such as pyridine or oxazoline, readily incorporated in the catalyst design, have been shown to enhance the selectivity for $\alpha$-olefins ${ }^{22,26}$ In addition, 
imine donor groups bearing bulky $\mathrm{N}$-aryl substituents offer the possibility of a rational control of the molecular weight of the products based on the same principles established by Brookhart for $\alpha$-diimine catalysts. ${ }^{35-40}$ Such phosphino-imine complexes constitute a versatile class of catalysts giving access to products ranging from light oligomers to high molecular weight polymers. However, a straightforward relationship between ligand structure and catalyst activity or selectivity is not always observed, as similar ligand designs can lead to very different results. ${ }^{8}$ One of the possible causes of such irregular behavior is the tendency of some of these ligands to undergo enolization, especially when basic cocatalysts such as MAO are used. ${ }^{35}$ By using nonenolizable phosphine-imine ligands, more stable catalysts are obtained which produce higher molecular weight polymers. ${ }^{35}$ The enolization problem can be avoided by replacing the $\mathrm{H}$ atoms on the position $\beta$ to the nitrogen donor with alkyl substituents. Alternatively, this problem can be circumvented inserting a heteroatom between the phosphorus and the imine functionality. However, direct replacement of the phosphino $\left(\mathrm{R}_{2} \mathrm{P}_{-}\right)$ for a phosphinito ( $\left.\mathrm{R}_{2} \mathrm{P}-\mathrm{O}-\right)$ fragment increases the chelate ring size, and this may induce changes in the geometry of the coordination sphere around the metal center. ${ }^{10,21,26,41}$ In contrast, phosphinito-imine ligands, depicted in Scheme 1, give rise to five-membered rings. These substances are tautomers of phosphinoamides, in which the phosphorus is bound to nitrogen. In recent years, a number of these phosphinoamide ligands have been prepared by reacting amide-based nucleophiles with chlorophosphines, ${ }^{42-46}$ but to the best of our knowledge, neither free nor complexed phosphinito-imine tautomers have been described so far. In spite of their closely related structures, the binding properties of phosphinito-imines and phosphinoamides are expected to be very different. The latter are known to coordinate solely through the phosphorus atom, ${ }^{43-49}$ and although they can form P,O chelates, ${ }^{45-47,49,50}$ these usually exhibit hemilabile behavior, the oxygen atom being easily displaced by incoming donor molecules. ${ }^{51}$ However, phosphinito-imines should form strong P,N chelates. In this paper we show that phosphinito-imine tautomers, readily prepared from carboxylic acid amides, are stabilized by steric factors when the $\mathrm{P}$ and $\mathrm{N}$ atoms bear bulky substituents. Nickel and palladium complexes of these non-enolizable P,N ligands have been prepared, and we report on their behavior as ethylene oligomerization catalysts.

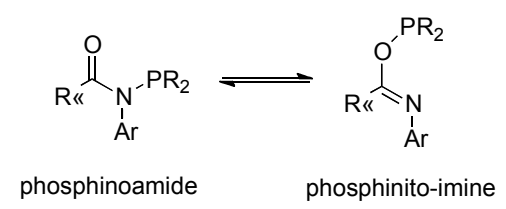

Scheme 1.

\section{Results and Discusión}

Synthesis of Ligands. The new ligands were prepared by deprotonation of $N$-(2,6-diisopropylphenyl)acetamide or $\mathrm{N}$-(2,6-diisopropylphenyl)pivalamide with $n$-BuLi or $\mathrm{NaH}$ at $-78{ }^{\circ} \mathrm{C}$, followed by reaction with the corresponding chlorophosphines, as shown in Scheme 2. The amide anions react smoothly with chlorodiisopropylphosphine at low temperatures. In both cases, the ${ }^{31} \mathrm{P}\left\{{ }^{1} \mathrm{H}\right\}$ NMR spectra of the reaction mixtures taken after stirring for $30 \mathrm{~min}$ at $-78{ }^{\circ} \mathrm{C}$ showed two new species in ca. 9:1 ratio, corresponding to the tautomers $\mathbf{1 / 2}$ or $\mathbf{3 / 4}$. Major resonances appear at ca $\delta 140 \mathrm{ppm}$ for both the acetamide (1) and pivalamide (3) derivatives while those of secondary products are shifted upfield, at $\delta 90 \mathrm{ppm}(2)$ and $65 \mathrm{ppm}$ (4). These products show signs of thermal instability. On standing at room temperature the ${ }^{31} \mathrm{P}\left\{{ }^{1} \mathrm{H}\right\}$ spectra of the mixtures show that the major/minor tautomer ratio gradually decreases with simultaneous appearance of 
a number of signals arising from decomposition products. Products $\mathbf{1 / 2}$ are particularly unstable and all attempts of isolation failed. The pivalamide derivatives $\mathbf{3} / \mathbf{4}$ are somewhat more stable, and after extraction with diethyl ether and evaporation of the solvent, essentially pure samples containing the major isomer, $\mathbf{3}$, were obtained, which enabled us to gather complete ${ }^{1} \mathrm{H}$ and ${ }^{13} \mathrm{C}\left\{{ }^{1} \mathrm{H}\right\}$ NMR data for this compound (see Experimental Section).

The reaction of the lithium salt of $\mathrm{N}$-(2,6-diisopropylphenyl)acetamide with $\mathrm{CIP}(t-\mathrm{Bu})_{2}$ is considerably slow, requiring 3 days at $100{ }^{\circ} \mathrm{C}$ to complete, but the products are thermally robust and do not decompose under such conditions. Again, the ${ }^{31} \mathrm{P}\left\{{ }^{1} \mathrm{H}\right\}$ NMR spectrum of the reaction mixture shows two signals at $\delta 142$ and 65 ppm in 95:5 intensity ratio for the corresponding tautomers (5/6). Crystallization from diethyl ether at $20^{\circ} \mathrm{C}$ gave a small amount of a solid containing the minor component and some starting amide. Evaporation of the mother liquor afforded compound $\mathbf{5}$ as a yellow oil in $95 \%$ yield. Solutions of ligand $\mathbf{5}$ in THF are indefinitely stable at room temperature.

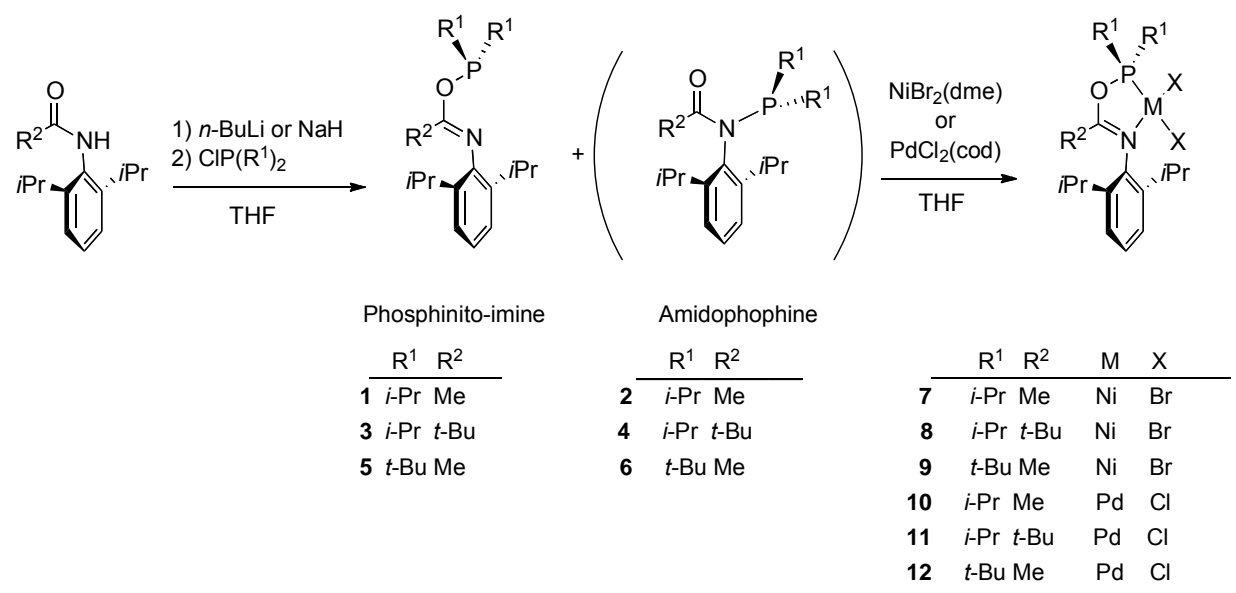

Scheme 2.

Although the ${ }^{1} \mathrm{H}$ and ${ }^{13} \mathrm{C}\left\{{ }^{1} \mathrm{H}\right\}$ NMR data obtained for $\mathbf{3}$ and $\mathbf{5}$ confirmed the presence of the $\mathrm{PR}_{2}$ and the $\mathrm{N}$-(2,6-diisopropylphenyl)amido groups, they provide no direct indications of whether the $\mathrm{P}$ atom is bound to $\mathrm{O}$ or $\mathrm{N}$. However, the deshielding of the ${ }^{31} \mathrm{P}$ resonance of the major isomers $(\mathbf{1}, \mathbf{3}$ or $\mathbf{5})$ suggests the presence of an electronegative O-bound group. Therefore, these can be reasonably assigned to the phosphinito-imine tautomers, while minor species $2, \mathbf{4}$ or $\mathbf{6}$ would have the phosphinoamide structure. This hypothesis finds support in the comparison with literature ${ }^{31} \mathrm{P}\left\{{ }^{1} \mathrm{H}\right\}$ NMR phosphinites $\left(\mathrm{E}_{2} \mathrm{P}-\mathrm{OR}\right)$ and phosphinoamides $\left(\mathrm{R}_{2} \mathrm{P}-\mathrm{NR}_{2}\right)$. For example, the chemical shifts of the phosphinoamide-phosphinites depicted in Figure 1 are very similar to those formed in our system. They give rise to low-field resonances at $\delta 110-$ $150 \mathrm{ppm}$ for the alkoxophosphine group and high-field ones at $\delta 50-60 \mathrm{ppm}$ for the phosphinoamide. ${ }^{52}$ It seems very likely that the relative stability of the phosphinito-imine and phosphinoamide tautomers is determined by steric factors. The phosphinoamide tautomer, usually favored over the phosphinito-imine, ${ }^{42-46}$ becomes destabilized in our system by the steric repulsions posed by the bulky $\mathrm{PR}_{2}$ and $\mathrm{N}-\mathrm{Ar}$ groups.

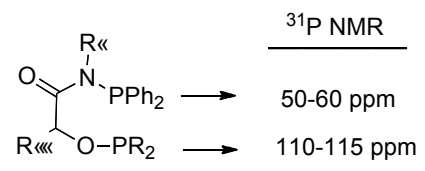


Figure 1. Typical ${ }^{31} \mathrm{P}$ chemical shifts for $\mathrm{R}_{2} \mathrm{P}-\mathrm{N}$ and $\mathrm{R}_{2} \mathrm{P}-\mathrm{O}$ linkages.

Nickel and Palladium Phosphinito-Imine Complexes. Reacting freshly prepared mixtures of tautomers $(\mathbf{1} / \mathbf{2}$ or $\mathbf{3 / 4})$ or the purified ligand 5 with equimolar amounts of $\mathrm{NiBr}_{2}(\mathrm{dme})$ (dme $=1,2$-dimethoxyethane) or $\mathrm{PdCl}_{2}$ (cod) (cod = 1,5-cyclooctadiene) leads exclusively to the $\mathrm{Ni}(\mathrm{II})$ and $\mathrm{Pd}(\mathrm{II})$ complexes $\mathbf{7}$ - 12 containing the P,N phosphinito-imine ligands (Scheme 2). The ${ }^{31} \mathrm{P}\left\{{ }^{1} \mathrm{H}\right\}$ spectra of crude reaction mixtures display a single resonance, confirming that only one isomer is produced. Thus, a rapid isomerization of the minor phosphinoamide tautomer takes place on complexation to the metal center. After workup, the complexes were isolated as crystalline, diamagnetic solids. In contrast with the free ligands, their complexes are thermally stable and can be exposed to air for short periods of time without noticeable decomposition. The diamagnetism of the nickel derivatives indicates that the phosphinito-imine ligand favors square-planar structures both in the solid state and in solution. This is somewhat unusual, for most P,N ligands form paramagnetic complexes with $\mathrm{NiX}_{2}$ moieties. ${ }^{21-37}$

The P,N coordination mode is supported by the ${ }^{31} \mathrm{P}\left\{{ }^{1} \mathrm{H}\right\}$ and $I R$ data, and confirmed by the X-ray structures of the complexes. The phosphorus spectra show a low field resonances at ca. $200 \mathrm{ppm}$ for the palladium derivatives and $166-198 \mathrm{ppm}$ for their nickel analogues, which is more consistent with a $\mathrm{R}_{2} \mathrm{P}-\mathrm{O}$ than with a $\mathrm{R}_{2} \mathrm{P}-\mathrm{N}$ fragment. In addition, $v(\mathrm{C}=\mathrm{N})$ absorption bands are observed in the $1590-1650 \mathrm{~cm}^{-1}$ region of the infrared spectra. The imine absorption of free ligand 5 at $1679 \mathrm{~cm}^{-1}$ shifts by ca. $20 \mathrm{~cm}^{-1}$ to lower frequency upon coordination to $\mathrm{Ni}$ and $\mathrm{Pd}$ in complexes $\mathbf{9}$ and $\mathbf{1 2}$.

All complexes 7 - 12 have been characterized by $X$ ray dffraction. Their crystal estructures are shown in Figure 2, and main bond distances and angles are collected in Table 1. All molecules are characterized by the flat 5-membered N,P chelate and a square planar coordination environment, with very small tetrahedral distortion. The distortion degree is measured by the torsion angle formed by the halide ligands and the $\mathrm{P}$ and $\mathrm{N}$ atoms (X1X2P1N1). This is very small and virtually identical for both complexes of ligand 1, but the derivatives of the relatively bulky ligands $\mathbf{3}$ and $\mathbf{5}$ show a slight tetrahedral distortion, somewhat larger for the $\mathrm{Ni}\left(\mathrm{ca} 8^{\circ}\right)$ than for the $\mathrm{Pd}$ complexes. The intra-annular $\mathrm{P}-\mathrm{O}, \mathrm{O}-\mathrm{C}$ and $\mathrm{C}=\mathrm{N}$ distances are unexceptional and essentially identical in all the complexes. The aryl ring lies perpendicular to the coordination plane, leaving the isopropyl groups pointing towards the axial positions of the metal center. In the pivalamide derivatives $\mathbf{8}$ and $\mathbf{1 1}$, the aryl ring is forced by the steric pressure of the bulky $t$-Bu substituent to come closer to the metal fragment. This is reflected in the wider C13-N1-C1 and narrower C1$\mathrm{N} 1-\mathrm{M}$ angles in these complexes. The lengths of $\mathrm{M}-\mathrm{X}$ bonds sense the different trans influence of the $\mathrm{P}$ and $\mathrm{N}$ donors, and those opposed to the more strongly donor phosphinito group are appreciably longer than those in trans to the imine fragment. Although the lengths of $\mathrm{Ni}-\mathrm{Br}$ and $\mathrm{Pd}-\mathrm{Cl}$ are similar, the differential effect of trans groups is less pronounced for Ni complexes (ca. $1.2 \%$ of the average length) than in the $\mathrm{Pd}$ derivatives (2 - $3 \%$ ). Complex 11 exhibits the largest $d_{\mathrm{M}-\mathrm{X}_{1}-}-d_{\mathrm{M}-\mathrm{x}_{2}}$ difference, due to the extra elongation of the $\mathrm{Pd}-\mathrm{Cl} 1$. This is probably caused by the steric pressure originated by the $t$-Bu substituent of the phosphinitoimine backbone, transmitted by the aryl ring to the nearby chloride ligand. The pressure of the aryl ring on the $\mathrm{Ni}-\mathrm{Br} 1$ bond of $\mathbf{8}$ has no noticeable effect on its length because it is efficiently released by the significant tetrahedral distortion of this complex. 

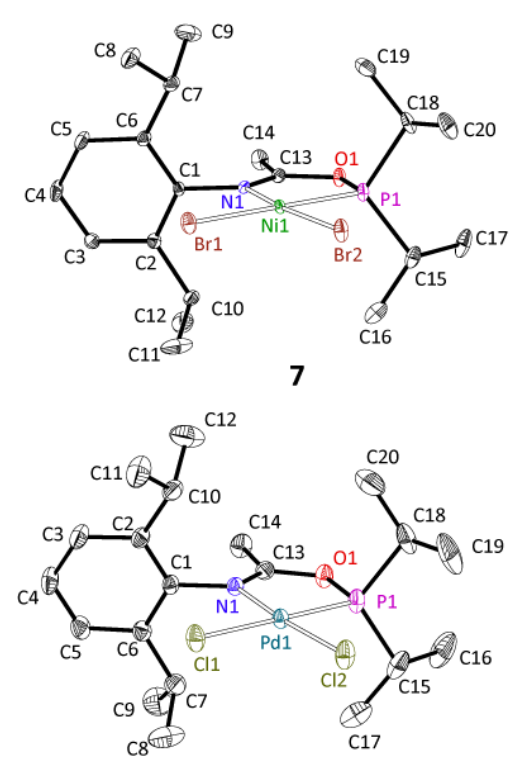

10
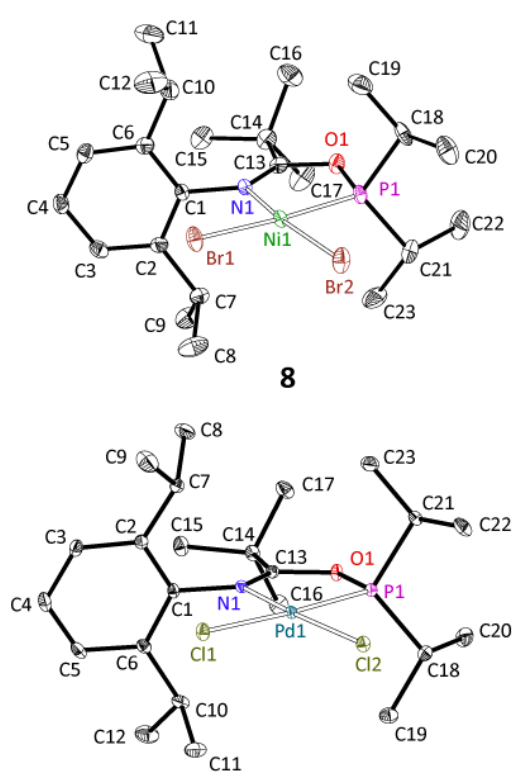

11
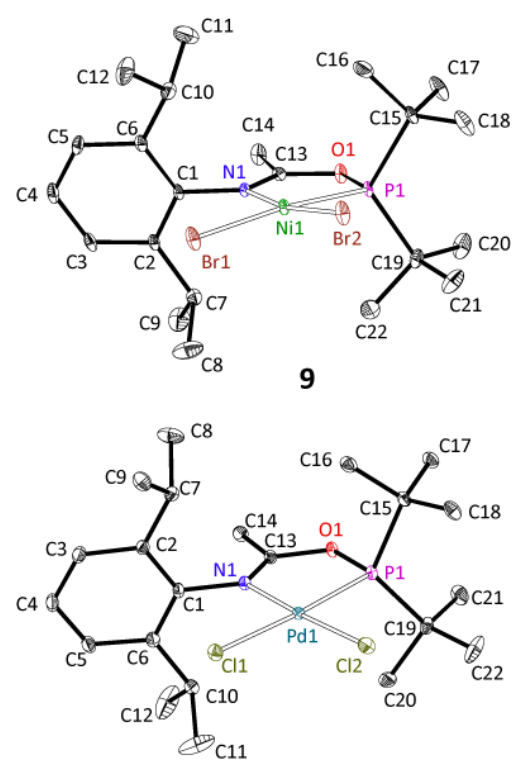

12

Figure 2. ORTEP views of complexes 7 - 12.

Table 1. Selected bond distances and angles for complexes 7 - $12(\mathrm{M}=\mathrm{Ni}$ or $\mathrm{Pd}, \mathrm{X}=\mathrm{Br}$ or $\mathrm{Cl})$.

\begin{tabular}{|c|c|c|c|c|c|c|}
\hline & 7 & 8 & 9 & 10 & 11 & $12^{a}$ \\
\hline M-P1 & $2.0974(9)$ & $2.089(2)$ & $2.1315(10)$ & $2.1685(8)$ & $2.1576(3)$ & $2.2042(5)$ \\
\hline M-N1 & $1.917(2)$ & $1.955(7)$ & $1.943(3)$ & $2.056(2)$ & 2.0769(10) & $2.0570(12)$ \\
\hline$M-X 2$ & $2.3027(5)$ & $2.3140(13)$ & $2.3168(7)$ & $2.2960(8)$ & $2.2972(3)$ & $2.2995(4)$ \\
\hline$M-X 1$ & $2.3318(5)$ & $2.3371(11)$ & $2.3477(6)$ & $2.3552(8)$ & $2.3748(3)$ & $2.3637(5)$ \\
\hline P1-O1 & $1.683(2)$ & $1.675(7)$ & $1.685(3)$ & $1.6696(11)$ & $1.6663(9)$ & $1.6696(11)$ \\
\hline O1-C13 & $1.341(4)$ & 1.339(11) & $1.333(5)$ & $1.3533(17)$ & $1.3583(14)$ & 1.3533(17) \\
\hline $\mathrm{N} 1=\mathrm{C} 13$ & $1.289(4)$ & $1.295(9)$ & $1.301(5)$ & $1.282(3)$ & $1.2916(15)$ & $1.2873(18)$ \\
\hline N1-C1 & 1.454(4) & 1.440(9) & $1.449(5)$ & $1.456(3)$ & $1.4454(15)$ & $1.4533(18)$ \\
\hline $\mathrm{X} 2-\mathrm{M}-\mathrm{X} 1$ & $94.710(18)$ & $93.28(5)$ & $92.46(2)$ & $93.98(3)$ & $93.545(12)$ & $90.735(14)$ \\
\hline X1-M-N1 & $97.02(8)$ & 99.41(17) & $96.36(10)$ & $95.66(6)$ & $97.54(3)$ & $94.56(3)$ \\
\hline X2-M-P1 & 83.81(3) & $83.43(7)$ & $87.32(3)$ & $88.38(3)$ & $87.077(12)$ & $92.866(15)$ \\
\hline X2-M-N1 & 168.06(8) & $166.34(17)$ & $169.54(10)$ & $170.17(6)$ & 168.34(3) & $174.60(3)$ \\
\hline X1-M-P1 & 178.50(3) & 173.14(9) & $173.73(4)$ & 177.33(3) & $177.284(12)$ & $176.155(13)$ \\
\hline P1-M-N1 & $84.47(8)$ & 84.47(18) & 84.53(10) & $81.94(6)$ & $82.02(3)$ & $81.87(3)$ \\
\hline M-N1-C1 & $123.36(2)$ & $118.7(4)$ & $125.3(2)$ & $123.28(2)$ & 116.41(7) & 123.04(9) \\
\hline C13-N1-C1 & $116.4(2)$ & $122.0(7)$ & 115.6(3) & $117.9(2)$ & $124.3(1)$ & $117.9(1)$ \\
\hline $\begin{array}{c}\mathrm{X} 1-\mathrm{X} 2-\mathrm{P} 1- \\
\mathrm{N} 1\end{array}$ & 2.14 & 8.24 & 8.84 & 2.14 & 4.81 & $1.85^{\mathrm{b}}$ \\
\hline
\end{tabular}

a) One of two independent molecules. b) $7.08^{\circ}$ in molecule 2 .

As discussed above, the diamagnetic, square-planar configuration of the $\mathrm{Ni}$ complexes is unusual among ( $\mathrm{P}-\mathrm{N}) \mathrm{NiX}_{2}$ complexes. Some examples of square-planar $\mathrm{Ni}(\mathrm{II})$ derivatives of phosphinito-pyridine ligands have been reported, which display square-planar structures in the solid state, ${ }^{23,26}$ but are paramagnetic in solution. ${ }^{23}$ The NMR spectra of the phosphinito-imine complexes of $\mathrm{Ni}$ and $\mathrm{Pd}$ in $\mathrm{CD}_{2} \mathrm{Cl}_{2}$ are very similar and typical of diamagnetic compounds, showing that their square-planar configurations are retained in solution. However, the room temperature spectra of the $\mathrm{Ni}$ complexes reveal some intriguing differences with those of their Pd counterparts. Whilst the spectra of the latter show sharp and well-defined 


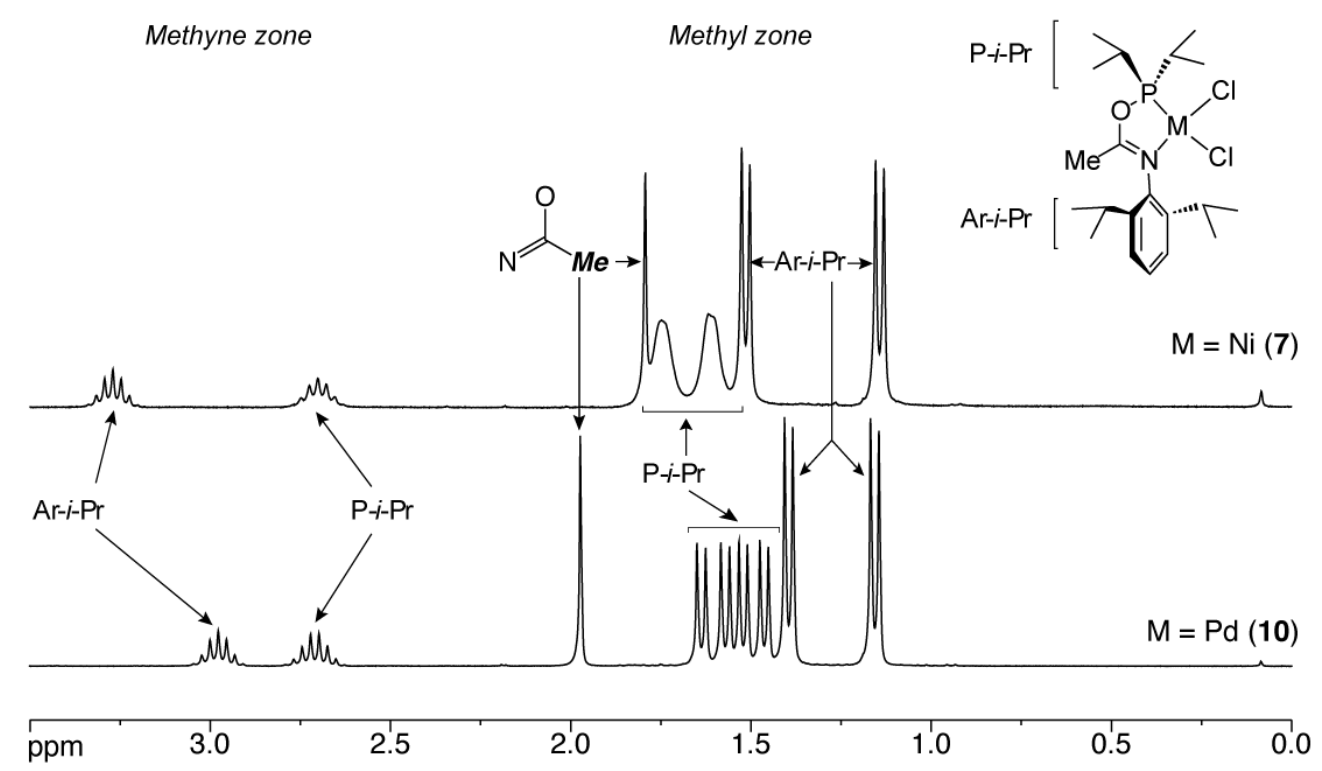

Figure 3. Room temperature spectrum of complexes 7 and $\mathbf{1 0}\left(\mathrm{CD}_{2} \mathrm{Cl}_{2}\right.$ high field region only).

signals, the ${ }^{31} \mathrm{P}$ signals of the Ni complexes are broad and $\mathrm{H}-\mathrm{P}$ couplings in the ${ }^{1} \mathrm{H}$ spectrum appear partially unresolved. Notably, signals arising from the P-bound isopropyl groups of the Ni complex appear broadened, while those of the 2,6 substituents of the aryl group are sharp and well resolved. These differences can be clearly seen in the high field of the ${ }^{1} \mathrm{H}$ spectra of compounds 7 and 10 , represented in Figure 3 , and suggest the occurrence of some fluxional process. In order to ascertain its nature, variable temperature ${ }^{1} \mathrm{H}$ and ${ }^{31} \mathrm{P}$ NMR studies were carried out on complex 7 and its $\mathrm{Pd}$ analogue, 10. The spectrum of the latter is essentially temperature-independent within the studied temperature range, but those of the nickel compound display significant shape variations. Below $253 \mathrm{~K}$, the slow exchange limit is reached and the spectrum shows wellresolved $\mathrm{H}-\mathrm{P}$ couplings. As the temperature rises, couplings to phoshorus progressively fade away in the proton spectra while the ${ }^{31} \mathrm{P}$ signal becomes broader. At $323 \mathrm{~K}$, the latter disappears in the baseline, and $\mathrm{H}$ $\mathrm{P}$ couplings are totally lost in the ${ }^{1} \mathrm{H}$ spectrum.

Selective loss of couplings is a common phenomenon in the NMR spectra of coordination or organometallic complexes. This phenomenon normally stems from the reversible dissociation of the bonds responsible for the transmission of the coupling. Obviously, this is not the case here since reversible P-C bond dissociation cannot occur. A rapid exchange between the diamagnetic square-planar complex with small amounts of a high spin $(S=1)$ tetrahedral isomer might account for the observations, and is in good agreement with the absence of similar effects in the spectra of the Pd derivatives (Figure 4). Since the ${ }^{31} \mathrm{P}$ atom is directly bound to the metal center, hyperfine coupling to the electronic spin provides an extremely efficient relaxation mechanism, leading to the observed broadening of the $\mathrm{P}$ resonance and to the effective cancellation of heteronuclear couplings to phosphorus. Assuming this explanation, a simulation of the methyl region of ${ }^{1} \mathrm{H}$ spectrum lineshape has been carried out (Figure 5; see Experimental for details). Figure 6 shows the Eyring plot for the computed exchange rates which provide the following activation parameters for the exchange process: $\Delta \mathrm{H}^{\ddagger}=10.4(9) \mathrm{Kcal} / \mathrm{mol}, \Delta S^{\ddagger}=-4(1) \mathrm{cal} / \mathrm{mol} \cdot \mathrm{K}$ and $\Delta \mathrm{G}^{\ddagger}=11.66(15) \mathrm{Kcal} / \mathrm{mol}$ at $298 \mathrm{~K}$. According to Hammond's postulate, the energy tetrahedral form probably is probably only slightly lower than the barrier of the observed exchange process. In order to assess this hypothesis, DFT calculations were performed to determine the relative energies of the square-planar and tetrahedral forms. As a first option, the 
hybrid functional B3LYP was used, but the calculation incorrectly predicted that the tetrahedral isomer should be more stable than the square planar by $3.0 \mathrm{Kcal} / \mathrm{mol}$. However, a second calculation with the pure functional BP86 provides the correct energy order with the tetrahedral species laying $10.6 \mathrm{Kcal} / \mathrm{mol}$ above the diamagnetic ground state, in good agreement with the experiment. It is known that, at least for some types of transition metal complexes, pure gradient-corrected functionals, such as BP86, perform better for the purpose of estimating spin state splitting energies. ${ }^{53}$ The structures representing the square-planar and tetrahedral forms of $\mathbf{7}$ shown in Figure 4 correspond to the BP86 optimized geometries.

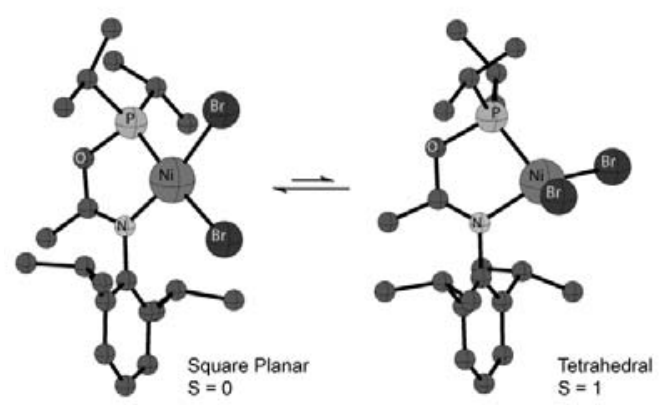

Figure 4. Square planar and tetrahedral geometries for complex 7 (BP86 optimized structures).

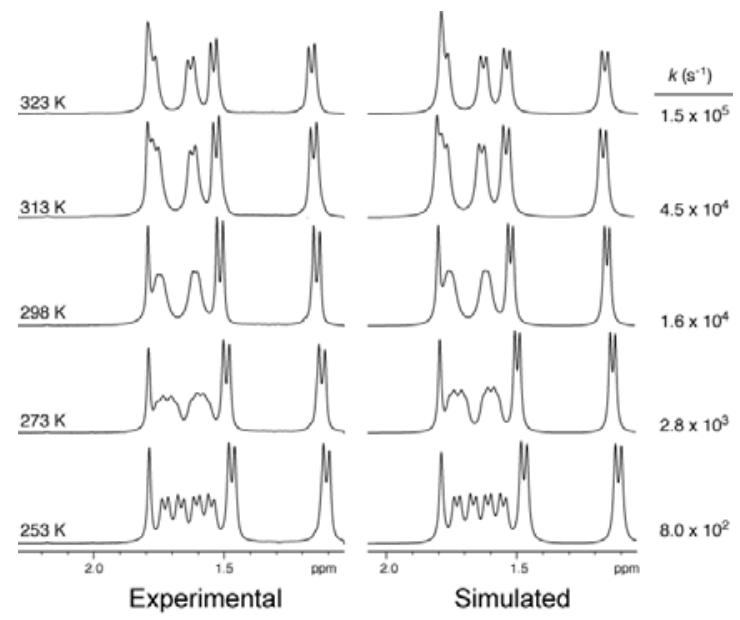

Figure 5. Experimental and simulated ${ }^{1} \mathrm{H}$ NMR spectra of compound 7 recorded at variable temperature (methyl zone).

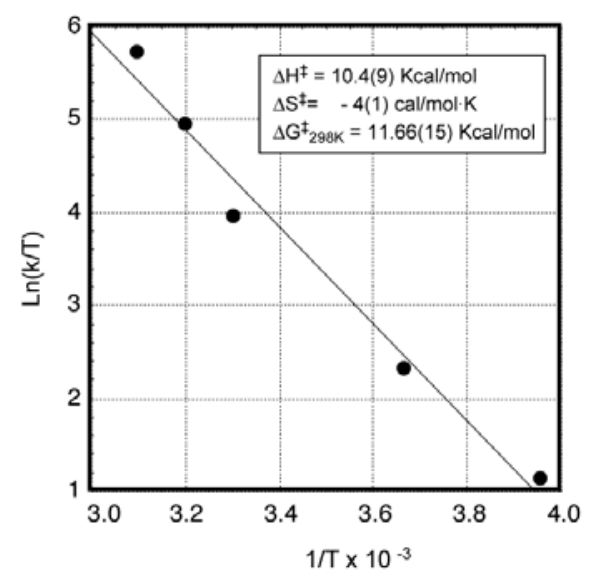

Figure 6. Eyring plot $(253-323 \mathrm{~K})$ of the computed rate constants and activation parameters. 


\section{Catalytic behavior of phosphinito-imine complexes. Catalytic oligomerization of ethylene.}

The catalytic activity of complexes 7-12 was investigated using modified methylalumoxane (MMAO) or diethylaluminum chloride (DEAC) as cocatalysts in toluene as solvent. The reactions were performed in $250 \mathrm{~mL}$ Fischer-Porter glass reactors fitted with an internal thermocouple and a septum-capped port for catalyst injection. The reactors were immersed in a thermostatic water bath at a preset temperature. Ethylene consumption and the internal reactor temperature were monitored continuously during the experiments.

The catalysts were screened in a series of experiments at $30^{\circ} \mathrm{C}$ and an ethylene pressure of 5 bar (standard conditions), which showed that the Ni complexes actively catalyze the oligomerization of ethylene into mixtures of butenes, hexenes and octenes, while the Pd complexes are catalytically inactive. No polyethylene precipitates when the reaction mixtures are treated with acidified methanol. In general, the results of quantitative GC analysis are in good agreement with the ethylene consumption data, confirming that no high molecular weight oligomers or polymers are produced. The Ni catalysts display low thermal stability, since their activity is sensibly reduced at $50^{\circ} \mathrm{C}$ and becomes negligible at $70^{\circ} \mathrm{C}$.

The preliminary study was extended to determine the optimum [Ni]/[Al] ratios (Table 2). Complex 7 achieves its best performance with relatively low loads of either MMAO or DEAC (200 or 150 equiv, respectively). Although 8 and $\mathbf{9}$ can also be activated with similar amounts of DEAC (8: 150 Equiv; 9: 200 Equiv), with MMAO a higher [Al]/[Ni] ratio of ca. 600 is required for efficient performance. In general, the effect of the catalyst/cocatalyst ratio on the activities is not dramatic but DEAC behaves as a much more effective co-catalyst than MMAO.

Table 2. Influence of the catalyst/cocatalyst ratio on the activity of complexes $7-9^{\mathrm{a}}$

\begin{tabular}{cccccccc}
\hline Catalyst & $\begin{array}{c}\text { Co- } \\
\text { catalyst }\end{array}$ & {$[\mathrm{Al}] / \mathrm{Ni}$} & $\begin{array}{c}\text { TOF } \\
\times 10^{-3}\end{array}$ & Catalyst & $\begin{array}{c}\text { Co- } \\
\text { catalyst }\end{array}$ & {$[\mathrm{Al}] / \mathrm{Ni}$} & $\begin{array}{c}\text { TOF } \\
\times 10^{-3}\end{array}$ \\
\hline 7 & MMAO & 1000 & 10.4 & $7^{\mathrm{b}}$ & DEAC & 250 & 186.9 \\
7 & MMAO & 750 & 14.9 & $7^{\mathrm{b}}$ & DEAC & 200 & 389.7 \\
7 & MMAO & 500 & 17.5 & $7^{\mathrm{b}}$ & DEAC & 175 & 834.4 \\
7 & MMAO & 250 & 20.1 & $7^{\mathrm{b}}$ & DEAC & 150 & 866.2 \\
7 & MMAO & 150 & 12.8 & $7^{\mathrm{b}}$ & DEAC & 100 & 528.3 \\
8 & MMAO & 1000 & 7.4 & $7^{\mathrm{b}}$ & DEAC & 50 & 518.1 \\
8 & MMAO & 500 & 9.8 & 8 & DEAC & 175 & 22.9 \\
9 & MMAO & 700 & 2.2 & 9 & DEAC & 300 & 54.6 \\
9 & MMAO & 600 & 2.6 & 9 & DEAC & 200 & 36.9 \\
9 & MMAO & 500 & 2.2 & 9 & DEAC & 100 & 20.2 \\
9 & MMAO & 400 & 1.8 & 9 & DEAC & 50 & 14.0 \\
9 & MMAO & 200 & 1.9 & & & &
\end{tabular}

a) Experimental conditions: $[\mathrm{Ni}]=2 \times 10^{-4} \mathrm{M}$, Solvent, toluene; total volume $\approx 20 \mathrm{~mL}, 30{ }^{\circ} \mathrm{C}, 4 \mathrm{bar}$ Reaction time, $1 \mathrm{~h}$ unless otherwise stated. b) Reaction time $3-5 \mathrm{~min}$.

Tables 3 and 4 collect data for a set of 60 min experiments carried out to compare the effect of catalyst structure, pressure and temperature on the catalytic activity and selectivity of the three nickel complexes. Complexes $\mathbf{7}$ and $\mathbf{8}$ exhibit very similar catalytic properties, and are much more active than $\mathbf{9}$. Upon activation with DEAC or MMAO, $\mathbf{7}$ and $\mathbf{8}$ give rise to very active catalysts, achieving ethylene turnover frequencies well above $10^{6}$ mole ethylene $/$ mole $\mathrm{Ni} \cdot \mathrm{h}^{-1}$ under favorable conditions. Monitoring ethylene consumption shows that upon activation at $30^{\circ} \mathrm{C}$ the activity reaches its peak within few seconds or minutes, 
Table 3. Activity and selectivity data for ethylene oligomerization with complexes 7-9 activated with MMAO. ${ }^{a}$

\begin{tabular}{|c|c|c|c|c|c|c|c|c|c|c|c|c|c|}
\hline & Cat & $\begin{array}{l}{\left[\mathrm{Ni}^{\mathrm{b}}{ }^{\mathrm{b}}\right.} \\
\mathrm{x} 10^{-5}\end{array}$ & $\begin{array}{l}{[\mathrm{Al}]^{\mathrm{b}}} \\
\mathrm{x} 10^{-2}\end{array}$ & $\begin{array}{l}\mathrm{P}^{\mathrm{c}} \\
\text { (bar) }\end{array}$ & $\begin{array}{c}\mathrm{T}^{\mathrm{d}} \\
\left({ }^{\circ} \mathrm{C}\right)\end{array}$ & $\begin{array}{c}\text { Yield }^{e} \\
\text { (grs) }\end{array}$ & $\begin{array}{c}\text { TOF }^{f} \\
\times 10^{-3} \\
\left(h^{-1}\right)\end{array}$ & $\begin{array}{c}\text { Max. } \\
\text { TOF }^{g} \\
\times 10^{-3} \\
\left(\mathrm{~h}^{-1}\right)\end{array}$ & $\begin{array}{c}\text { TOF }_{60}{ }^{\mathrm{h}} \\
\times 10^{-3} \\
\left(\mathrm{~h}^{-1}\right)\end{array}$ & $\begin{array}{c}\mathrm{t}_{1 / 2}^{\mathrm{i}}{ }^{2} \\
(\mathrm{~min})\end{array}$ & $\begin{array}{c}\Delta \mathrm{T}^{\mathrm{j}} \\
\left({ }^{\circ} \mathrm{C}\right)\end{array}$ & $\mathrm{C}_{4}: \mathrm{C}_{6}: \mathrm{C}_{8}$ & $\begin{array}{c}\mathrm{C}_{4}: \\
\text { 1- } \mathrm{C}_{4} \mathrm{H}_{8} / \\
\text { 2-trans/ } \\
\text { 2-cis }\end{array}$ \\
\hline 1 & 7 & 21.0 & 4.4 & 5 & 30 & 3.41 & 13.5 & 37.8 & 4.0 & 12 & 4.7 & $78: 20: 3$ & 13:30:57 \\
\hline 2 & 7 & 2.6 & 4.1 & 5 & 30 & 0.33 & 8.9 & 15.9 & 8.0 & 60 & 0.2 & $71: 29: 0$ & $29: 11: 60$ \\
\hline 3 & 7 & 2.6 & 4.1 & 9 & 30 & 0.52 & 16.6 & 25.0 & 12.4 & $>60$ & 2.1 & $71: 29: 0$ & $41: 9: 50$ \\
\hline 4 & 7 & 21.0 & 4.4 & 5 & 0 & 3.76 & 14.8 & 37.1 & 10.0 & 13 & 5.0 & $83: 12: 5$ & $8: 25: 67$ \\
\hline 5 & 8 & 20.1 & 12.1 & 5 & 30 & 1.39 & 16.4 & 71.1 & 6.0 & 8 & 9.9 & $64: 23: 13$ & $27: 16: 58$ \\
\hline 6 & 8 & 2.6 & 12.5 & 5 & 30 & 0.16 & 5.2 & 28.9 & 2.1 & 7 & 0.3 & $77: 23: 0$ & $61: 11: 28$ \\
\hline 7 & 8 & 10.3 & 12.3 & 9 & 30 & 4.62 & 36.6 & 102.3 & 23.6 & 11 & 7.3 & $77: 20: 3$ & $16: 14: 70$ \\
\hline 8 & 8 & 20.0 & 12.0 & 5 & 0 & 2.77 & 11.0 & 36.7 & 6.9 & 9 & 5.3 & $80: 17: 3$ & $19: 23: 58$ \\
\hline 9 & 8 & 10.2 & 12.0 & 5 & 0 & 1.10 & 14.7 & 36.8 & $55.3^{k}$ & $>60$ & 1.9 & $81: 17: 2$ & $29: 20: 51$ \\
\hline 10 & 9 & 20.0 & 12.0 & 5 & 30 & 0.10 & 0.4 & 2.2 & 0.0 & 8 & 1.4 & $50: 40: 10$ & 100:0:0 \\
\hline 11 & 9 & 20.0 & 12.0 & 5 & 30 & 0.23 & 0.9 & 7.7 & 0.0 & 7 & 1.7 & $54: 42: 4$ & $94: 3: 4$ \\
\hline 12 & 9 & 20.0 & 12.0 & 9 & 30 & 0.09 & 0.4 & 9.0 & 0.0 & 7 & 0.5 & $66: 34: 0$ & $94: 3: 4$ \\
\hline 13 & 9 & 20.0 & 12.0 & 5 & 0 & 2.18 & 8.6 & 26.8 & 2.8 & 14 & 6.3 & $65: 31: 4$ & $94: 2: 3$ \\
\hline
\end{tabular}

a) Reaction time, $60 \mathrm{~min}$; total volume, $42 \mathrm{~mL}$; solvent, toluene. b) Mole $\cdot \mathrm{L}^{-1} \mathrm{c}$ ) Ethylene pressure. d) External bath temperature. e) Oligomer yield, from GC analysis. f) Average activity (TOF, in mole Ethylene/mole $\mathrm{Ni} \cdot \mathrm{h}$ ). g) Maximum TOF, from ethylene consumption curves h) Activity after $60 \mathrm{~min}$. i) Time for $50 \%$ activity decay j) Increase of internal reactor temperature. k) Reaction rate increases continuously during the experiment.

Table 4. Activity and selectivity data for ethylene oligomerization with complexes 7-9 activated with DEAC. ${ }^{a}$

\begin{tabular}{|c|c|c|c|c|c|c|c|c|c|c|c|c|c|}
\hline & Cat. & $\begin{array}{l}{\left[\mathrm{Ni}^{\mathrm{b}}\right.} \\
\mathrm{x} 10^{-5}\end{array}$ & $\begin{array}{l}{[\mathrm{Al}]^{\mathrm{b}}} \\
\mathrm{x} 10^{-2}\end{array}$ & $\begin{array}{c}\mathrm{P}^{\mathrm{c}} \\
\text { (bar) }\end{array}$ & $\begin{array}{c}\mathrm{T}^{\mathrm{d}} \\
\left({ }^{\circ} \mathrm{C}\right)\end{array}$ & $\begin{array}{c}\text { Yield }^{e} \\
\text { (grs) }\end{array}$ & $\begin{array}{c}\text { TOF }^{f} \\
\times 10^{-3} \\
\left(h^{-1}\right)\end{array}$ & $\begin{array}{c}\text { Max. } \\
\text { TOF }^{9} \\
\times 10^{-3} \\
\left(\mathrm{~h}^{-1}\right) \\
\end{array}$ & $\begin{array}{c}\text { TOF }_{60}{ }^{h} \\
\times 10^{-3} \\
\left(h^{-1}\right)\end{array}$ & $\begin{array}{c}\mathrm{t}_{1 / 2}^{\mathrm{i}} \\
(\mathrm{min})\end{array}$ & $\begin{array}{c}\Delta \mathrm{T}^{\mathrm{j}} \\
\left({ }^{\circ} \mathrm{C}\right)\end{array}$ & $\mathrm{C}_{4}: \mathrm{C}_{6}: \mathrm{C}_{8}$ & $\begin{array}{c}\mathrm{C}_{4}: \\
\text { 1- } \mathrm{C}_{4} \mathrm{H}_{8} / \\
\text { 2-trans/ } \\
\text { 2-cis }\end{array}$ \\
\hline 1 & 7 & 2.6 & 3.1 & 5 & 30 & 2.43 & 77.5 & 1662.5 & 0.0 & 5 & 27.0 & $80: 20: 0$ & $48: 31: 21$ \\
\hline 2 & 7 & 1.0 & 3.1 & 5 & 30 & 1.94 & 154.1 & 738.0 & 0.0 & 6 & 5.9 & $88: 12: 0$ & $40: 23: 37$ \\
\hline 3 & 7 & 1.0 & 3.1 & 9 & 30 & 3.13 & 240.2 & 3837.6 & 0.0 & 9 & 25.3 & $87: 12: 0$ & $50: 20: 30$ \\
\hline 4 & 7 & 2.6 & 3.1 & 5 & 0 & 0.31 & 9.9 & 12.5 & $12.5^{\mathrm{k}}$ & $>60$ & 0.9 & $88: 12: 0$ & $17: 34: 49$ \\
\hline 5 & 8 & 19.9 & 3.5 & 5 & 30 & 18.57 & 73.5 & 322.9 & 5.0 & 22 & 40.6 & $75: 23: 0$ & $17: 46: 37$ \\
\hline 6 & 8 & 2.6 & 3.1 & 5 & 30 & 3.05 & 96.8 & 1812.6 & 0.0 & 4 & 30.1 & $82: 18: 0$ & $32: 30: 18$ \\
\hline 7 & 8 & 2.6 & 3.1 & 9 & 30 & 4.26 & 135.3 & 1685.3 & 5.2 & 4 & 45.2 & $84: 14: 1$ & $36: 31: 33$ \\
\hline 8 & 8 & 10.3 & 3.1 & 5 & 0 & 12.57 & 99.7 & 490.3 & 0.0 & 9 & 54.8 & $81: 18: 2$ & $4: 51: 45$ \\
\hline 9 & 9 & 19.7 & 3.9 & 5 & 30 & 2.63 & 10.4 & 13.8 & 7.0 & 60 & 1.2 & $90: 10: 0$ & $33: 41: 25$ \\
\hline 10 & 9 & 19.7 & 3.9 & 9 & 30 & 3.69 & 14.7 & 17.5 & 14.6 & 41 & 0.9 & $98: 2: 0$ & $0: 77: 23$ \\
\hline 11 & 9 & 19.7 & 3.9 & 5 & 0 & 0.81 & 2.2 & 6.8 & $1.4^{k}$ & $>60$ & 5.3 & $93: 14: 0$ & $42: 25: 33$ \\
\hline
\end{tabular}

a) Reaction time, $60 \mathrm{~min}$; total volume, $42 \mathrm{~mL}$; solvent, toluene. b) Mole. $\mathrm{L}^{-1} \mathrm{c}$ ) Ethylene pressure. d) External bath temperature. e) Oligomer yield, from GC analysis. f) Average activity (TOF, in mole Ethylene/mole Ni $\cdot \mathrm{h}$ ). g) Maximum TOF, from ethylene consumption curves h) Activity after $60 \mathrm{~min}$. i) Time for $50 \%$ activity decay j) Increase of internal reactor temperature. k) Reaction rate increases continuously during the experiment.
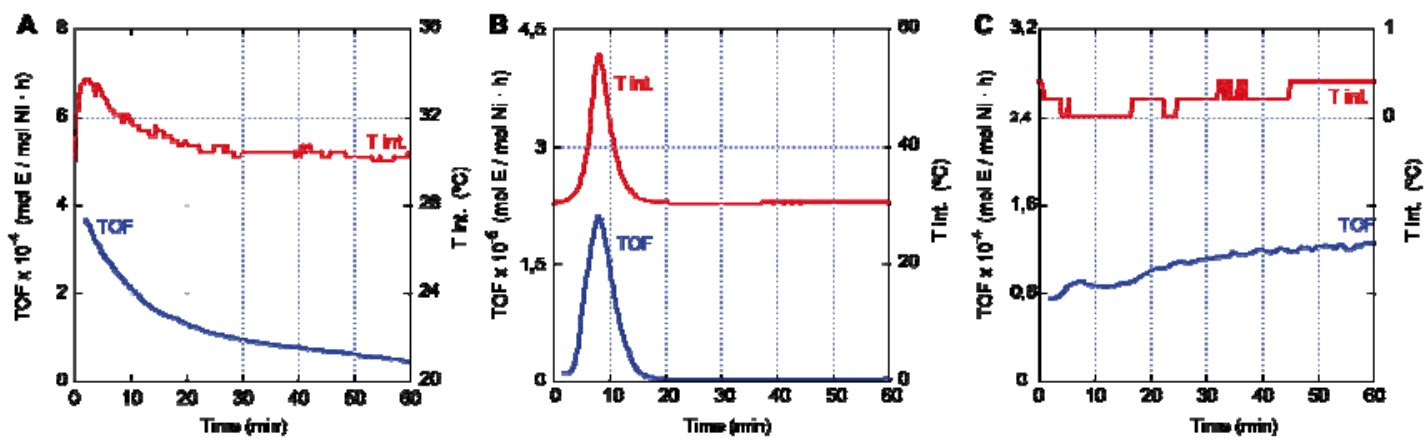

Figure 7. Representative examples of activity profiles observed with phosphinito-imine catalysts. The lower curve (blue) represents the activity variation (TOF) and the upper (red), the internal reactor temperature. A, Typical activity curve, corresponding to entry 1, Table 3; B, "pulsed" activity, showing a narrow activity maximum, entry 3, Table 4; C slow catalyst activation at low temperature, entry 4, Table 4.

decaying afterwards during the rest of the experiment (Figure 7, A). The activation process is accompanied by a visible color change of the mixture from the characteristc purple-red of the complexes to yellow. However, as discussed below, the use of diluted catalyst solutions or lower operating temperatures may lead 
to very different activity profiles. Apart from the typical example A, Figure 7 shows other two significant examples of such profiles, $B$ and $C$.

Although catalysts produced with DEAC are more active than those generated with MMAO, the latter are longer lived. For example, the time required by the catalytic activity to fall to $50 \%$ of its maximum value $\left(t_{1 / 2}\right)$ is $4-6$ min with $\mathbf{7}$ or $\mathbf{8}$ when activated with DEAC and $>7$ min with MMAO under standard conditions. In contrast, the catalyst formed with $\mathbf{9}$ and DEAC shows low but sustained activity under the same conditions (Table 4, entry 9). A possible explanation for the faster deactivation of 7- 8 / DEAC is that heat released by the high activity levels favors catalyst decomposition. As can be seen in Figure 7, the internal reactor temperature parallels the activity profile, temperature peaks of $30-40{ }^{\circ} \mathrm{C}$ being observed when high activity levels are reached. In most cases (profile A), after the initial activity peak the temperature declines and the catalyst performance reaches an almost stable regime in which the activity decay is relatively slow. With MMAO, the catalysts retain significant activity after 60 min runs $\left(\mathrm{TOF}_{60}\right)$, while DEAC-activated systems are usually inactive before the end of the experiments. In order to avoid excessive heating, the dose of the nickel catalyst was decreased according to the activity observed in preliminary experiments, while maintaining constant other parameters such as the co-catalyst concentration and reaction volume. However, even under high dilution conditions systems generated from $\mathbf{7}$ or $\mathbf{8}$ and DEAC are active enough to induce significant temperature peaks (entries 2, 3, 6, 7, Table 4). After the sharp activity maximum the catalyst deactivates, resulting in a fast reaction "pulse" rather than a sustained process (profile $B$ ). In an attempt to increase the rate of heat transfer we used external cooling to $0^{\circ} \mathrm{C}$, but at this temperature catalyst performance becomes limited by incomplete activation (profile $\mathrm{C}$ ). In these experiments (Table 2, entries 4 and 9 and Table 3, entry 9 ), ethylene consumption curves show that the activity rises slowly, in some cases without even reaching a true maximum. In experiment 8 , Table 4 , the $0^{\circ} \mathrm{C}$ bath was used in combination with a larger load of catalyst 8. This induced faster catalyst activation, but the internal temperature rose to nearly the same level observed under standard conditions, resulting in a similar deactivation rate.

The influence of the ethylene pressure on the activity of complexes 7 - 9 is not clear-cut. In general, the average activity increases by a factor $1.5-2$ when the pressure rises from 5 to 9 bar (compare, for example, entries 2 and 3, in Table 3, or entries 6 and 7 in Table 4). The origin of this effect is not evident, because global productivity figures do not depend exclusively on the specific activity of the catalyst but also on its decay rate, which can be in turn influenced by monomer concentration, as well as by changes in the internal reactor temperature. Complex relationships between these factors lead to the different activity profiles such as those illustrated by Figure 7, which makes very difficult to extract any conclusion from the mere comparison of average experiment activity. In part, the positive influence of pressure on global productivity might originate in a decrease of the catalyst decay rate. Indeed, catalysts survive somewhat

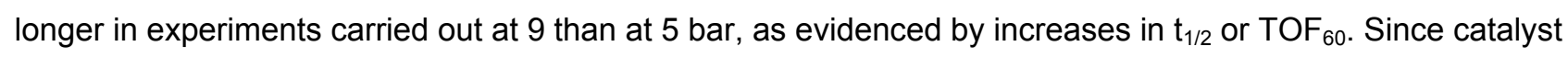
deactivation probably has only a minor effect on the maximum activity level that the catalysts achieve shortly after the beginning of the experiment $\left(\mathrm{TOF}_{\text {max }}\right)$, this is a better descriptor for the effect of pressure on the

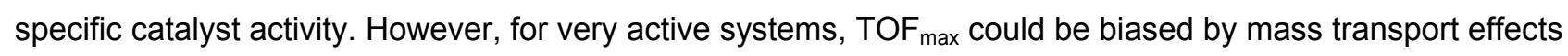
and by the simultaneous increase of the internal temperature. Thus, experiments developing mild activities are probably best suited for the analysis of the pressure effect. Thus, for complexes $\mathbf{7}$ and $\mathbf{8}$ activated with MMAO, the TOF ${ }_{\text {max }}$ parameter increases significantly on going from 5 to 9 bar, suggesting that the rate 
limiting step is directly dependent on the monomer concentration. However, the less active catalyst 9 is insensitive to pressure changes (either with MMAO or DEAC). This difference suggests that the ratedetermining step of the ethylene oligomerization process could be different for the latter.

The C4/C6/C8 selectivity ratio of the $\mathrm{Ni}$ phosphino-imine catalysts is hardly influenced by temperature or pressure, but there is a dramatic effect of the nature of the co-catalyst. Activation with DEAC increases the selectivity for $\mathrm{C} 4$ products and leads to lower amounts of hexenes and octenes than MMAO. Diagrams shown in Figure 8 represent the average product distributions obtained for each of these catalyst/cocatalyst combinations in the studied ranges of pressure and temperature. As can be seen, complexes 7 and $\mathbf{8}$ bear a remarkable resemblance in terms of selectivity, while the profile of the mixtures of oligomers generated with $\mathbf{9}$ is less alike. Curiously, while the latter forms the least selective catalyst when activated with MMAO, with DEAC it produces almost exclusively butenes with $>90 \%$ selectivity.
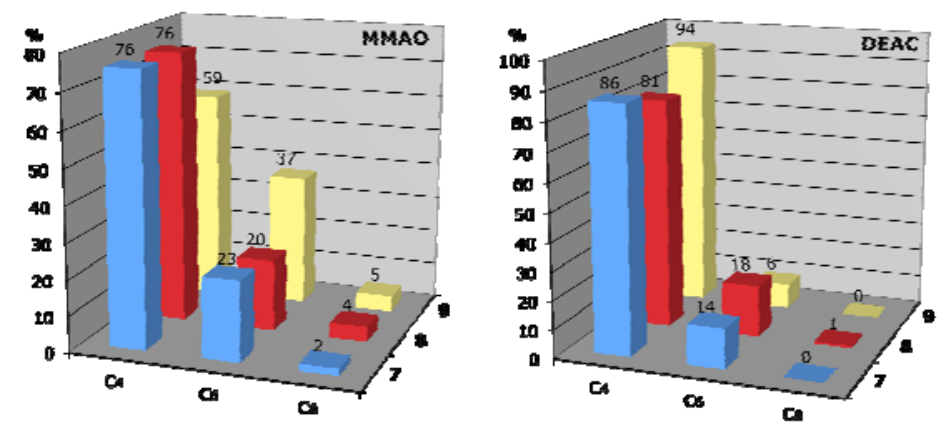

Figure 8. Selectivity of complexes $\mathbf{7}-\mathbf{9}$ for ethylene oligomerization upon activation with MMAO and DEAC, calculated as averages for all experiments. Percent values (\%) are given on the top of each column.

The ratio of 1-butene and 2-cis- and 2-trans-butene is widely variable, probably due to secondary isomerization reactions that are difficult to control. Complex 9 is again exceptional on this regard, since in combination with MMAO the $\mathrm{C} 4$ fraction produced consistently contains $>94 \% 1$-butene, suggesting that the isomerization process does not operate in this case. This selectivity is not seen with DEAC.

The preference of the nickel phosphinito-imine catalysts for ethylene dimerization is rather surprising considering that these compounds contain a 2,6-diisopropylphenylimino group, which is specifically designed to increase the molecular weight of the products by hindering chain transfer to the monomer. ${ }^{54-58}$ Indeed, structurally related phosphino-imine complexes containing the same bulky aryl substituent produce either heavy Schulz-Flory mixtures of oligomers ${ }^{37}$ (with $\alpha=0.8-0.9$ ) or medium to high molecular weight polyethylenes. ${ }^{27,29}$ The similarity of the product distributions obtained with $\mathbf{7}$ and 8 and the differences observed for 9 suggest that selectivity is controlled by the $\mathrm{PR}^{1}{ }_{2}$ group, while it is relatively insensitive to changes in the $\alpha$ substituent of the imine fragment ( $\mathrm{Me}$ or $t-\mathrm{Bu}$ ). The different behavior of phosphinito-imine and phosphine-imine complexes and the lack of significant effects of subtituents on the ligand backbone could be taken as an indication of significant alterations of the phosphinito-imine ligand on activation by aluminum co-catalysts, i. e., cleavage of the P-O bond leading to imine-free species. However, the oligomer distribution is reminiscent of those obtained with $\mathrm{Ni}$ catalysts containing phosphinito-heterocycle ${ }^{10,26}$ and other P,N ligands. ${ }^{23,25}$ Furthermore, Braunstein has shown that phosphinito-type ligands form stable complexes with aluminum alkyls without $\mathrm{P}-\mathrm{O}$ cleavage. ${ }^{26}$ If the phosphinito-imine chelates maintain their 
integrity under our catalysis conditions, a unusually low energy barrier for the chain transfer process would be necessary to explain the selectivity for low molecular weight products.

\section{Conclusions}

A new family of phosphinito-imine ligands is readily available from the reaction of the anions of the bulky amides $N$-(2,6-diisopropylphenyl)acetamide or $N$-(2,6-diisopropylphenyl)pivalamide with chlorodiisopropylphosphine or chloroditertbutylphosphine. The new ligands are formed together with minor amounts of the corresponding amidophosphine tautomers. However, upon reaction with suitable precursors such as $\mathrm{NiBr}_{2}(\mathrm{dme})$ or $\mathrm{PdCl}_{2}(\mathrm{cod})$, the mixtures are cleanly transformed into the phosphinito-imine complexes 7 - 12, which are obtained in excellent yields and are thermally stable in solution and the solid state. These have square-planar structures characteristic of a low spin configuration although in solution the nickel complexes undergo exchange with the high-spin tetrahedral isomer with $\Delta G^{\ddagger}=11.66(15) \mathrm{Kcal} / \mathrm{mol}$. Upon activation with MMAO or DEAC, nickel complexes $\mathbf{7}$ - 9 become active ethylene oligomerization/polymerization catalysts producing mainly butenes, and minor amounts of hexenes and octenes. Both the activity and the selectivity of these catalysts are strongly influenced by the nature of the co-catalyst. In general, DEAC leads to higher activities and better selectivities for ethylene dimerization. Complexes $\mathbf{7}$ and $\mathbf{8}$ have very similar catalytic properties reaching extremely high catalytic activities (TOF), over $10^{6} \mathrm{~h}^{-1}$ when activated with DEAC. Catalysts generated from 9 are considerably less active but offer somewhat improved selectivity control, allowing $>90 \%$ butenes when activated with DEAC, and high selectivity for $\alpha$-olefins with MMAO.

\section{Experimental Section}

General Considerations. All experiments were carried out under dry nitrogen using standard Schlenk techniques. Solvents were rigorously dried and degassed before use. Microanalyses were performed by the Microanalytical Service of the Instituto de Investigaciones Químicas (Sevilla, Spain). Infrared spectra were recorded on a Bruker Vector 22 spectrometer, and NMR spectra on Bruker DRX 400 and $500 \mathrm{MHz}$ and Bruker DPX $300 \mathrm{MHz}$ spectrometers. The ${ }^{1} \mathrm{H}$ and ${ }^{13} \mathrm{C}\left\{{ }^{1} \mathrm{H}\right\}$ NMR resonances of the solvent were used as the internal standard, but the chemical shifts are reported with respect to TMS. ${ }^{31} \mathrm{P}$ NMR resonances are referenced to external $85 \% \mathrm{H}_{3} \mathrm{PO}_{4}$. NMR chemical shifts are given in ppm and coupling constants in $\mathrm{Hz}$. GC analyses were performed in a Agilent model HP 6890 chromatograph equipped with a HPGASPRO column and a TCD detector, using $\mathrm{CH}_{2} \mathrm{Cl}_{2}$ as the internal standard. Compounds $\mathrm{NiBr}_{2}(\mathrm{dme})$ and ${ }^{59} \mathrm{PdCl}_{2}$ (cod) ${ }^{60}$ were prepared according to literature procedures. The amides 2,6-i $-\mathrm{Pr}_{2} \mathrm{C}_{6} \mathrm{H}_{3} \mathrm{NHC}(\mathrm{O}) \mathrm{Me}$ and 2,6-i $\mathrm{Pr}_{2} \mathrm{C}_{6} \mathrm{H}_{3} \mathrm{NHC}(\mathrm{O})-t-$ Bu were synthesized by standard procedures. ${ }^{61}$

Ligand 1: A solution of the amide 2,6- $\mathrm{Pr}_{2} \mathrm{C}_{6} \mathrm{H}_{3} \mathrm{NHC}(\mathrm{O}) \mathrm{Me}(219 \mathrm{mg}, 1 \mathrm{mmol})$ in thf $(20 \mathrm{ml})$, stirred at $-78^{\circ} \mathrm{C}$ was successively treated with $0.63 \mathrm{~mL}(1 \mathrm{mmol})$ of a $1.6 \mathrm{M}$ solution of $n \mathrm{BuLi}$ in hexane, and $0.167 \mathrm{~mL}(1$ $\mathrm{mmol})$ of $i \mathrm{Pr}_{2} \mathrm{PCl}$. The stirring was continued for $30 \mathrm{~min}$. at the same temperature, and the solution was directly used for the synthesis of complexes. This solution contains a mixture of the corresponding 
phosphinito-imine (1) and phosphinoamide (2) tautomers. ${ }^{31} \mathrm{P}\left\{{ }^{1} \mathrm{H}\right\} \mathrm{NMR}\left(25^{\circ} \mathrm{C}\right.$, thf, $\left.121 \mathrm{MHz}\right)$ : two signals in ca. 90:10 intensity ratio at $\delta 139.0$ (s, isomer 1 :) and 90.0 (s, isomer 2 ).

Ligand 3. Sodium hydride (14 $\mathrm{mg}, 0.6 \mathrm{mmol}$ ) was suspended in a solution the amide 2,6$\operatorname{Pr}_{2} \mathrm{C}_{6} \mathrm{H}_{3} \mathrm{NHC}(\mathrm{O}) t \mathrm{Bu}\left(150 \mathrm{mg}, 0.57 \mathrm{mmol}\right.$ ) in $10 \mathrm{ml}$ of thf. The mixture was stirred at $40{ }^{\circ} \mathrm{C}$ for $1 \mathrm{~h}$. After removing the $\mathrm{NaH}$ excess by centrifugation, the solution was cooled to $-78{ }^{\circ} \mathrm{C}$, and $0.5 \mathrm{~mL}$ of a $1 \mathrm{M}$ solution of $\mathrm{Pr}_{2} \mathrm{PCl}(0.5 \mathrm{mmol})$ in thf were added with stirring. The mixture was allowed to react at the same temperature for $30 \mathrm{~min}$. The resulting solution, containing a ca. 90:10 mixture of the phopsphinito-imine (3) and phosphinoamide (4) tautomers, was used directly for the synthesis of the complexes. ${ }^{31} \mathrm{P}\left\{{ }^{1} \mathrm{H}\right\}$ NMR $(25$ ${ }^{\circ} \mathrm{C}$, thf): $\delta 140.2$ (s, isomer 3); 65.0 (s, isomer 4). A spectroscopically pure sample of 3 was obtained by evaporating the solvent under reduced pressure, extracting the residue with diethyl ether, filtering and taking the solution to dryness. ${ }^{1} \mathrm{H}$ NMR $\left(25^{\circ} \mathrm{C}, \mathrm{CD}_{2} \mathrm{Cl}_{2}, 300 \mathrm{MHz}\right): \delta 1.07$ (dd, $6 \mathrm{H},{ }^{3} \mathrm{~J}_{\mathrm{HH}}=7 \mathrm{~Hz},{ }^{3} \mathrm{~J}_{\mathrm{HP}}=14 \mathrm{~Hz}$, $\mathrm{PCHMeMe}$ ), $1.16\left(\mathrm{dd}, 6 \mathrm{H},{ }^{3} \mathrm{~J}_{\mathrm{HH}}=7 \mathrm{~Hz},{ }^{3} J_{\mathrm{HP}}=11 \mathrm{~Hz}, \mathrm{PCHMeMe}\right), 1.24(\mathrm{~s}, 9 \mathrm{H}, t B u C(\mathrm{O}) \mathrm{N}), 1.33$ (d, overlapping signal, Aryl-CHMeMe), 1.35 (d, overlapping signal, Aryl-CHMeMe), $1.83(\mathrm{~m}, 2 \mathrm{H}, \mathrm{PCHMe}$ ), 3.09 (hept, $2 \mathrm{H},{ }^{3} \mathrm{~J}_{\mathrm{HH}}=7 \mathrm{~Hz}$, Aryl-CHMe $), 7.08\left(\mathrm{t}, 1 \mathrm{H},{ }^{3} \mathrm{~J}_{\mathrm{HH}}=7 \mathrm{~Hz}, p-\mathrm{CH}_{\mathrm{ar}}\right), 7.14\left(\mathrm{~d}, 2 \mathrm{H},{ }^{3} \mathrm{~J}_{\mathrm{HH}}=7 \mathrm{~Hz}, \mathrm{~m}-\mathrm{CH}_{\mathrm{ar}}\right.$ ). ${ }^{13} \mathrm{C}\left\{{ }^{1} \mathrm{H}\right\}$ NMR $\left(25^{\circ} \mathrm{C}, \mathrm{CD}_{2} \mathrm{Cl}_{2}, 75 \mathrm{MHz}\right): \delta 17.8$ (d, $\left.{ }^{2} J_{\mathrm{CP}}=3 \mathrm{~Hz}, \mathrm{PCHMeMe}\right), 17.9$ (s, PCHMeMe), 22.6 (s, Aryl-CHMeMe), 23.9 (s, Aryl-CHMeMe), $27.9\left(\mathrm{~d},{ }^{1} J_{\mathrm{CP}}=23 \mathrm{~Hz}, \mathrm{PCHMe}\right.$ ), $28.8\left(\mathrm{~s}, \mathrm{Me}_{3} \mathrm{CC}(\mathrm{O}) \mathrm{N}\right), 29.1$ (s, Aryl$\mathrm{CHMe}_{2}$ ), 30.4 (s, $\mathrm{Me}_{3} \mathrm{CC}(\mathrm{O}) \mathrm{N}$ ), 122.6 (s, $m-\mathrm{CH}_{\mathrm{ar}}$ ), 123.2 (s, $p-\mathrm{CH}_{\mathrm{ar}}$ ), 136.4 (s, N- $\mathrm{C}_{\mathrm{ar}}$ ), 143.2 (s, o- $\mathrm{C}_{\mathrm{ar}}$ ), 160.7 (d, $\left.{ }^{2} J_{\mathrm{CP}}=6 \mathrm{~Hz}, \mathrm{Me}_{3} \mathrm{CC}(\mathrm{O}) \mathrm{N}\right)$.

Ligand 5. A glass ampoule with a Young ${ }^{\circledR}$ Teflon tap and magnetic stirrer was charged with a thf solution of 2,6- $-\mathrm{Pr}_{2} \mathrm{C}_{6} \mathrm{H}_{3} \mathrm{NHC}(\mathrm{O}) \mathrm{Me}(1.2 \mathrm{~g}, 5.86 \mathrm{~mol})$ in $20 \mathrm{~mL}$ of THF. The solution was cooled to $-78{ }^{\circ} \mathrm{C}$ and treated with $3.66 \mathrm{~mL}$ of a $1.6 \mathrm{M}$ solution of $n \mathrm{BuLi}$ in hexane $(5.86 \mathrm{mmol})$. After stirring for $5 \mathrm{~min}$ at this temperature, $1.017 \mathrm{~g}(5.86 \mathrm{mmol})$ of $t \mathrm{Bu}_{2} \mathrm{PCl}$ were added. The cooling bath was removed, the tap closed and the mixture stirred at $100{ }^{\circ} \mathrm{C}$ for 3 days. The resulting solution contains a $95: 5$ mixture of 5 and $6 .{ }^{31} \mathrm{P}\left\{{ }^{1} \mathrm{H}\right\}$ NMR $\left(25^{\circ} \mathrm{C}\right.$, thf, $121 \mathrm{MHz}$ ): $\delta 142.3(\mathrm{~s}, 5) . \delta 65.4(\mathrm{~s}, 6)$. The solvent was then removed under reduced pressure, and the residue extracted with $50 \mathrm{~mL}$ of $\mathrm{CH}_{2} \mathrm{Cl}_{2}$. The solution was evaporated again, and the residue dissolved in diethyl ether. A white solid containing the phosphinoamide tautomer 6 and some starting amide precipitated when the solution was stored at $-30^{\circ} \mathrm{C}$. The solution was filtered and taken to dryness, leaving $\mathbf{5}$ as a yellow oil. Yield: $95 \%$ (2.02 g). IR (thf solution): $v(\mathrm{C}=\mathrm{N}) 1679 \mathrm{~cm}^{-1} .{ }^{1} \mathrm{H}$ NMR $\left(25^{\circ} \mathrm{C}, \mathrm{C}_{6} \mathrm{D}_{6}, 300 \mathrm{MHz}\right): \delta 1.11(\mathrm{~d}, 6 \mathrm{H}$, $\left.{ }^{3} J_{\mathrm{HH}}=7 \mathrm{~Hz}, \mathrm{Ar}-\mathrm{CHMeMe}\right), 1.14\left(\mathrm{~d}, 6 \mathrm{H},{ }^{3} \mathrm{~J}_{\mathrm{HH}}=7 \mathrm{~Hz}, \mathrm{Ar}-\mathrm{CHMeMe}\right), 1.21\left(\mathrm{~d}, 18 \mathrm{H},{ }^{3} \mathrm{~J}_{\mathrm{HP}}=12 \mathrm{~Hz}, \mathrm{P}(\mathrm{t}-\mathrm{Bu})_{2}\right), 1.76$ (s, 3H, MeC(O)N), 2.87 (hept, $\left.2 \mathrm{H},{ }^{3} \mathrm{~J}_{\mathrm{HH}}=7 \mathrm{~Hz}, \mathrm{Ar}-\mathrm{CHMeMe}\right), 7.02\left(\mathrm{t}, 1 \mathrm{H},{ }^{3} \mathrm{~J}_{\mathrm{HH}}=7 \mathrm{~Hz}, p-\mathrm{CH}_{\mathrm{ar}}\right), 7.1(\mathrm{~d}, 2 \mathrm{H}$, $\left.{ }^{3} \mathrm{~J}_{\mathrm{HH}}=7 \mathrm{~Hz}, m-\mathrm{CH}_{\mathrm{ar}}\right) .{ }^{13} \mathrm{C}\left\{{ }^{1} \mathrm{H}\right\} \mathrm{NMR}\left(25^{\circ} \mathrm{C}, \mathrm{C}_{6} \mathrm{D}_{6}, 75 \mathrm{MHz}\right): \delta 17.7(\mathrm{~s}, \mathrm{MeC}(\mathrm{O}) \mathrm{N}), 23.1$ (s, Ar-CHMeMe), 23.5 (s, Ar-CHMeMe), $27.6\left(\mathrm{~d},{ }^{2} J_{\mathrm{CP}}=17 \mathrm{~Hz}, \mathrm{PCMe}\right.$ ), 28.3 (s, Ar-CHMeMe), 35.1 (d, ${ }^{1} J_{\mathrm{CP}}=28 \mathrm{~Hz}, \mathrm{PCMe}_{3}$ ), 123.1 $\left(\mathrm{s}, m-\mathrm{CH}_{\mathrm{ar}}\right), 123.3\left(\mathrm{~s}, p-\mathrm{CH}_{\mathrm{ar}}\right), 138.1\left(\mathrm{~s}, \mathrm{o}-\mathrm{C}_{\mathrm{ar}}\right), 144.3\left(\mathrm{~s}, \mathrm{~N}-\mathrm{C}_{\mathrm{ar}}\right), 160.7\left(\mathrm{~d},{ }^{2} J_{\mathrm{CP}}=6 \mathrm{~Hz}, \mathrm{MeC}(\mathrm{O}) \mathrm{N}\right)$.

Synthesis of $\mathrm{Ni}\left[N\left(2,6-i \mathrm{Pr}_{2} \mathrm{C}_{6} \mathrm{H}_{3}\right)=\mathrm{C}\left(\left(\mathrm{CH}_{3}\right) \mathrm{OPiPr}_{2}\right)\right] \mathrm{Br}_{2}(7)$. A thf solution of ligand 1 (1 mmol) prepared in situ as described above was added to a suspension of $\mathrm{NiBr}_{2}(\mathrm{dme})(308 \mathrm{mg}, 1 \mathrm{mmol})$ in $10 \mathrm{~mL}$ of thf cooled to $-40{ }^{\circ} \mathrm{C}$. The reaction mixture was allowed to warm to room temperature. After stirring for $30 \mathrm{~min}$, the solvent was evaporated under vacuum, and the red residue extracted with $60 \mathrm{~mL}$ of $\mathrm{CH}_{2} \mathrm{Cl}_{2}$ and filtered. The 
solution was then taken to dryness, the residue washed with $2 \times 20 \mathrm{~mL}$ of hexane and recrystallized from a mixture $\mathrm{CH}_{2} \mathrm{Cl}_{2}$ : toluene $(2: 1)$ at $-10{ }^{\circ} \mathrm{C}$ to afford compound 7 as a red crystalline solid. Yield: $71 \%(0.39 \mathrm{~g})$. Anal. Calcd for $\mathrm{C}_{20} \mathrm{H}_{34} \mathrm{Br}_{2} \mathrm{NNiOP}$ : C, 43.36; $\mathrm{H}, 6.19$; N, 2.53. Found: C, 43.09; $\mathrm{H}, 6.28 ; \mathrm{N}, 2.51$. IR (Nujol mull): $v(\mathrm{C}=\mathrm{N}) 1596 \mathrm{~cm}^{-1} .{ }^{1} \mathrm{H}$ NMR $\left(25^{\circ} \mathrm{C}, \mathrm{CD}_{2} \mathrm{Cl}_{2}, 300 \mathrm{MHz}\right): \delta 1.14\left(\mathrm{~d}, 6 \mathrm{H},{ }^{3} \mathrm{~J}_{\mathrm{HH}}=7 \mathrm{~Hz}\right.$, Aryl-CHMeMe $), 1.51$ (d, 6H, ${ }^{3} \mathrm{~J}_{\mathrm{HH}}=7 \mathrm{~Hz}$, Aryl-CHMeMe), 1.62 (bs, 6H, PCHMeMe), 1.75 (bs, 6H, PCHMeMe), 1.79 (s, 3H, $\operatorname{MeC}(\mathrm{O}) \mathrm{N}), 2.70(\mathrm{~m}, 2 \mathrm{H}, \mathrm{PCHMe}), 3.27$ (hept, $\left.2 \mathrm{H},{ }^{3} \mathrm{~J}_{\mathrm{HH}}=7 \mathrm{~Hz}, \operatorname{Aryl}-\mathrm{CHMe} \mathrm{M}_{2}\right), 7.13\left(\mathrm{~d}, 2 \mathrm{H},{ }^{3} \mathrm{~J}_{\mathrm{HH}}=7 \mathrm{~Hz}, m-\right.$ $\left.\mathrm{CH}_{\mathrm{ar}}\right), 7.24\left(\mathrm{t}, 1 \mathrm{H},{ }^{3} \mathrm{~J}_{\mathrm{HH}}=7 \mathrm{~Hz}, p-\mathrm{CH}_{\mathrm{ar}}\right) .{ }^{13} \mathrm{C}\left\{{ }^{1} \mathrm{H}\right\} \mathrm{NMR}\left(25^{\circ} \mathrm{C}, \mathrm{CD}_{2} \mathrm{Cl}_{2}, 75 \mathrm{MHz}\right): \delta 16.6$ (s, PCHMeMe), 17.7 (s, MeC(O)N), 18.5 (s, PCHMeMe), 23.5 (s, Aryl-CHMeMe), 23.8 (s, Aryl-CHMeMe), 29.4 (s, Aryl-CHMe ${ }_{2}$ ), 29.8 (s, $\mathrm{PCHMe}$ ), 123.9 (s, $m-\mathrm{CH}_{\mathrm{ar}}$ ), 128.1 (s, $p-\mathrm{CH}_{\mathrm{ar}}$ ), 140.6 (s, N-C ar), 141.6 (s, o- $C_{\mathrm{ar}}$ ), 173.7 (s, $\mathrm{MeC}(\mathrm{O}) \mathrm{N}) \cdot{ }^{31} \mathrm{P}\left\{{ }^{1} \mathrm{H}\right\} \mathrm{NMR}\left(25^{\circ} \mathrm{C}, \mathrm{CD}_{2} \mathrm{Cl}_{2}, 121 \mathrm{MHz}\right): \delta 178.0$ (bs).

Synthesis of $\mathrm{Ni}\left[N\left(2,6-i \mathrm{Pr}_{2} \mathrm{C}_{6} \mathrm{H}_{3}\right)=\mathrm{C}\left(\left(\mathrm{CH}_{3}\right)_{3} \mathrm{OPiPr}\right)\right] \mathrm{Br}_{2}$ (8). A thf solution of ligand $\mathbf{3}(0.5 \mathrm{mmol})$ prepared in situ as described above was added at $-78^{\circ} \mathrm{C}$ to $154 \mathrm{mg}$ of $\mathrm{NiBr}_{2}(\mathrm{dme})(0.5 \mathrm{mmol})$ suspended in $10 \mathrm{~mL}$ of thf. The reaction mixture was stirred and allowed to warm to room temperature over $30 \mathrm{~min}$. The solvent was evaporated under reduced pressure, affording a red solid that was extracted with $40 \mathrm{~mL}$ of $\mathrm{CH}_{2} \mathrm{Cl}_{2}$. The solution was taken to dryness, the residue washed $3 \times 20 \mathrm{~mL}$ of hot diethyl ether (to remove any $\mathrm{N}$ arylacetamide remaining in the mixture) and recrystallized from a mixture $\mathrm{CH}_{2} \mathrm{Cl}_{2}$ : toluene $(2: 1)$ at $-10{ }^{\circ} \mathrm{C}$ to yield compound 8 as a red crystalline solid. Yield: $89 \%(0.26 \mathrm{~g})$. Anal. Calcd for $\mathrm{C}_{23} \mathrm{H}_{40} \mathrm{Br}_{2} \mathrm{NNiOP}: \mathrm{C}, 46.35$; $\mathrm{H}, 6.76 ; \mathrm{N}, 2.35$. Found: C, 46.85; $\mathrm{H}, 6.98 ; \mathrm{N}, 2.27$. IR (Nujol mull): $v(\mathrm{C}=\mathrm{N}) 1646 \mathrm{~cm}^{-1} .{ }^{1} \mathrm{H}$ NMR $\left(25^{\circ} \mathrm{C}\right.$, $\left.\mathrm{CD}_{2} \mathrm{Cl}_{2}, 300 \mathrm{MHz}\right): \delta 1.09(\mathrm{~s}, 9 \mathrm{H}, t \mathrm{BuC}(\mathrm{O}) \mathrm{N}), 1.30\left(\mathrm{~d}, 6 \mathrm{H},{ }^{3} J_{\mathrm{HH}}=7 \mathrm{~Hz}\right.$, Aryl-CHMeMe), 1.63 (bs, 6H, $\mathrm{PCHMeMe}$ ), $1.73\left(\mathrm{~d}, 6 \mathrm{H},{ }^{3} \mathrm{~J}_{\mathrm{HH}}=7 \mathrm{~Hz} \text {, Aryl-CHMeMe), } 1.75 \text { (bs, 6H, PCHMeMe), } 2.68 \text { (m, 2H, PCHMe }\right)_{2}$, $3.23\left(\mathrm{~h}, 2 \mathrm{H},{ }^{3} \mathrm{~J}_{\mathrm{HH}}=7 \mathrm{~Hz}\right.$, Aryl-CHMe 2$), 7.04\left(\mathrm{~d}, 2 \mathrm{H},{ }^{3} \mathrm{~J}_{\mathrm{HH}}=8 \mathrm{~Hz}, m-\mathrm{CH}_{\mathrm{ar}}\right), 7.19\left(\mathrm{t}, 1 \mathrm{H},{ }^{3} \mathrm{~J}_{\mathrm{HH}}=7 \mathrm{~Hz}, p-\mathrm{CH}_{\mathrm{ar}}\right)$. ${ }^{13} \mathrm{C}\left\{{ }^{1} \mathrm{H}\right\}$ NMR $\left(25^{\circ} \mathrm{C}, \mathrm{CD}_{2} \mathrm{Cl}_{2}, 75 \mathrm{MHz}\right): \delta 16.8$ (s, PCHMeMe), 18.7 (s, PCHMeMe), 23.4 (s, Aryl-CHMeMe), 24.5 (s, Aryl-CHMeMe), 29.2 (s, Me $\mathrm{CC}(\mathrm{O}) \mathrm{N}$ ), 29.3 (s, Aryl-CHMe ${ }_{2}$ ), 30.1 (s, $\mathrm{PCHMe}_{2}$ ), 41.6 (s, $\mathrm{Me}_{3} \mathrm{CC}(\mathrm{O}) \mathrm{N}$ ), 123.3 (s, $m-\mathrm{CH}_{\mathrm{ar}}$ ), 128.4 (s, $\left.p-\mathrm{CH}_{\mathrm{ar}}\right), 140.5$ (s, N-Car), 141.5 (s, o- $\left.C_{\mathrm{ar}}\right), 177.5$ (s, $t \mathrm{BuC}(\mathrm{O}) \mathrm{N}$ ). ${ }^{31} \mathrm{P}\left\{{ }^{1} \mathrm{H}\right\} \operatorname{NMR}\left(25^{\circ} \mathrm{C}, \mathrm{CD}_{2} \mathrm{Cl}_{2}, 121 \mathrm{MHz}\right): \delta 166.6(\mathrm{bs})$.

Synthesis of $\mathrm{Ni}\left[N\left(2,6-i \mathrm{Pr}_{2} \mathrm{C}_{6} \mathrm{H}_{3}\right)=\mathrm{C}\left(\left(\mathrm{CH}_{3}\right) \mathrm{OPtBu}\right)\right] \mathrm{Br}_{2}(\mathbf{9}) .2 \mathrm{~mL}(1 \mathrm{mmol})$ of a $0.5 \mathrm{M}$ thf solution of ligand $\mathbf{5}$ was added to a suspension of $\mathrm{NiBr}_{2}(\mathrm{dme})(308 \mathrm{mg}, 1 \mathrm{mmol})$ in $10 \mathrm{~mL}$ of thf cooled to $-60{ }^{\circ} \mathrm{C}$. The reaction mixture was allowed to warm to room temperature while stirred. After $30 \mathrm{~min}$, the solvent was removed under vacuum, and the red solid thus obtained was extracted with $60 \mathrm{~mL}$ of $\mathrm{CH}_{2} \mathrm{Cl}_{2}$ and filtered. The solution was then taken to dryness. The residue was washed with $2 \times 20 \mathrm{~mL}$ of hexane and recrystallized from a mixture $\mathrm{CH}_{2} \mathrm{Cl}_{2}$ : toluene $(2: 1)$ at $-10{ }^{\circ} \mathrm{C}$ to afford compound 9 as a red crystalline solid. Yield: $72 \%(0.42 \mathrm{~g})$. Anal. Calcd for $\mathrm{C}_{22} \mathrm{H}_{38} \mathrm{Br}_{2} \mathrm{NNiOP}$ : C, 45.50; $\mathrm{H}, 6.58$; N, 2.41. Found: C, 45.62; $\mathrm{H}, 6.44 ; \mathrm{N}, 2.36$. IR (Nujol mull): $v(\mathrm{C}=\mathrm{N}) 1606 \mathrm{~cm}^{-1} .{ }^{1} \mathrm{H}$ NMR $\left(25^{\circ} \mathrm{C}, \mathrm{CD}_{2} \mathrm{Cl}_{2}, 300 \mathrm{MHz}\right): \delta 1.14\left(\mathrm{~d}, 6 \mathrm{H},{ }^{3} \mathrm{~J}_{\mathrm{HH}}=7 \mathrm{~Hz}\right.$, Aryl-CHMeMe$)$, $1.51\left(\mathrm{~d}, 6 \mathrm{H},{ }^{3} \mathrm{~J}_{\mathrm{HH}}=7 \mathrm{~Hz}\right.$, Aryl-CHMeMe), 1.78 (bs, $\left.18 \mathrm{H}, \mathrm{PCMe}_{3}\right), 1.80(\mathrm{~s}, 3 \mathrm{H}, \mathrm{MeC}(\mathrm{O}) \mathrm{N}), 3.23(\mathrm{~m}, 2 \mathrm{H}$, Aryl$\left.\mathrm{CHMe}_{2}\right), 7.12\left(\mathrm{~d}, 2 \mathrm{H},{ }^{3} \mathrm{~J}_{\mathrm{HH}}=8 \mathrm{~Hz}, m-\mathrm{CH}_{\mathrm{ar}}\right), 7.23\left(\mathrm{t}, 1 \mathrm{H},{ }^{3} \mathrm{~J}_{\mathrm{HH}}=8 \mathrm{~Hz}, p-\mathrm{CH}_{\mathrm{ar}}\right) \cdot{ }^{13} \mathrm{C}\left\{{ }^{1} \mathrm{H}\right\} \mathrm{NMR}\left(25^{\circ} \mathrm{C}, \mathrm{CD}_{2} \mathrm{Cl}_{2}, 75\right.$ $\mathrm{MHz}$ ): $\delta 18.1(\mathrm{~s}, \mathrm{MeC}(\mathrm{O}) \mathrm{N}$ ), 23.6 (s, Aryl-CHMeMe), 23.9 (s, Aryl-CHMeMe), 28.9 (s, PCMe 3 ), 29.4 (s, Aryl$\mathrm{CHMe}_{2}$ ), 42.7 (s, $\mathrm{PCMe}_{3}$ ), $123.9\left(\mathrm{~s}, m-\mathrm{CH}_{\mathrm{ar}}\right), 128.1$ (s, $\left.p-\mathrm{CH}_{\mathrm{ar}}\right), 140.9\left(\mathrm{~s}, \mathrm{~N}-\mathrm{C}_{\mathrm{ar}}\right.$ ), 141.8 (s, o- $C_{\mathrm{ar}}$ ), 173.6 (s, $\operatorname{MeC}(\mathrm{O}) \mathrm{N}) .{ }^{31} \mathrm{P}\left\{{ }^{1} \mathrm{H}\right\} \operatorname{NMR}\left(25^{\circ} \mathrm{C}, \mathrm{CD}_{2} \mathrm{Cl}_{2}, 121 \mathrm{MHz}\right): \delta 198.0$ (bs). 
Synthesis of $\operatorname{Pd}\left[N\left(2,6-i \mathrm{Pr}_{2} \mathrm{C}_{6} \mathrm{H}_{3}\right)=\mathrm{C}\left(\left(\mathrm{CH}_{3}\right) \mathrm{OPiPr}_{2}\right)\right] \mathrm{Cl}_{2}$ (10). $20 \mathrm{~mL}$ of a thf solution of ligand 1 (1 mmol) prepared in situ as described above was added at $-78{ }^{\circ} \mathrm{C}$ to a suspension of $\mathrm{PdCl}_{2}(\mathrm{cod})(285 \mathrm{mg}, 1 \mathrm{mmol})$ in $10 \mathrm{~mL}$ of thf. The reaction mixture was stirred while allowed to warm to room temperature over $1 \mathrm{~h}$. The solvent was evaporated under vacuum, and the residue extracted with $50 \mathrm{~mL}$ of $\mathrm{CH}_{2} \mathrm{Cl}_{2}$. The solution was then taken to dryness, affording a yellow solid that was recrystallized from thf at $-10^{\circ} \mathrm{C}$ to yield compound 10. Yield: 96 \% (0.56 g). Anal. Calcd for $\mathrm{C}_{20} \mathrm{H}_{34} \mathrm{Cl}_{2} \mathrm{NOPPd}$ : C, 46.48; $\mathrm{H}, 6.68 ; \mathrm{N}, 2.73$. Found: $\mathrm{C}, 46.36 ; \mathrm{H}$, 6.57; N, 2.86. IR (Nujol mull): $v(\mathrm{C}=\mathrm{N}) 1604 \mathrm{~cm}^{-1} .{ }^{1} \mathrm{H}$ NMR $\left(25^{\circ} \mathrm{C}, \mathrm{CD}_{2} \mathrm{Cl}_{2}, 300 \mathrm{MHz}\right): \delta 1.15\left(\mathrm{~d}, 6 \mathrm{H},{ }^{3} J_{\mathrm{HH}}=7\right.$ $\mathrm{Hz}$, Aryl-CHMeMe), $1.40\left(\mathrm{~d}, 6 \mathrm{H},{ }^{3} \mathrm{~J}_{\mathrm{HH}}=7 \mathrm{~Hz}\right.$, Aryl-CHMeMe), $1.43\left(\mathrm{dd}, 6 \mathrm{H},{ }^{3} \mathrm{~J}_{\mathrm{HH}}=7 \mathrm{~Hz},{ }^{3} \mathrm{~J}_{\mathrm{HP}}=20 \mathrm{~Hz}\right.$, $\mathrm{PCHMeMe}$ ), $1.60\left(\mathrm{dd}, 6 \mathrm{H},{ }^{3} \mathrm{~J}_{\mathrm{HH}}=7 \mathrm{~Hz},{ }^{3} \mathrm{~J}_{\mathrm{HP}}=14 \mathrm{~Hz}, \mathrm{PCHMeMe}\right), 1.97$ (s, 3H, MeC(O)N), 2.71 (d hept, 2H, ${ }^{3} \mathrm{~J}_{\mathrm{HH}}=7 \mathrm{~Hz},{ }^{2} \mathrm{~J}_{\mathrm{HP}}=14 \mathrm{~Hz}, \mathrm{PCHMe}$ ), 2.99 (hept, $2 \mathrm{H},{ }^{3} \mathrm{~J}_{\mathrm{HH}}=7 \mathrm{~Hz}, \operatorname{Aryl}-\mathrm{CHMe}$ ), $7.20\left(\mathrm{~d}, 2 \mathrm{H},{ }^{3} \mathrm{~J}_{\mathrm{HH}}=8 \mathrm{~Hz}, m-\right.$ $\left.\mathrm{CH}_{\mathrm{ar}}\right), 7.32\left(\mathrm{t}, 1 \mathrm{H},{ }^{3} \mathrm{~J}_{\mathrm{HH}}=8 \mathrm{~Hz}, p-\mathrm{CH}_{\mathrm{ar}}\right) \cdot{ }^{13} \mathrm{C}\left\{{ }^{1} \mathrm{H}\right\} \mathrm{NMR}\left(25^{\circ} \mathrm{C}, \mathrm{CD}_{2} \mathrm{Cl}_{2}, 75 \mathrm{MHz}\right): \delta 16.4\left(\mathrm{~d},{ }^{2} \mathrm{~J}_{\mathrm{CP}}=3 \mathrm{~Hz}\right.$, $\mathrm{PCHMeMe}$ ), 17.2 (s, MeC(O)N), 17.2 (d, ${ }^{2} J_{\mathrm{CP}}=1 \mathrm{~Hz}, \mathrm{PCHMeMe}$ ), 23.4 (s, Aryl-CHMeMe), 23.6 (s, ArylCHMeMe), 29.2 (s, Aryl-CHMe $), 30.0$ (d, ${ }^{1} J_{\mathrm{CP}}=24 \mathrm{~Hz}, \mathrm{PCHMe}$ ), 124.0 (s, $m-\mathrm{CH}_{\mathrm{ar}}$ ), 128.6 (s, $\left.p-\mathrm{CH}_{\mathrm{ar}}\right), 139.3$ (s, N-C $\left.C_{\text {ar }}\right), 141.7\left(\mathrm{~s}, \mathrm{o}-\mathrm{C}_{\mathrm{ar}}\right), 174.2(\mathrm{~s}, \mathrm{MeC}(\mathrm{O}) \mathrm{N}) \cdot{ }^{31} \mathrm{P}\left\{{ }^{1} \mathrm{H}\right\} \mathrm{NMR}\left(25^{\circ} \mathrm{C}, \mathrm{CD}_{2} \mathrm{Cl}_{2}, 121 \mathrm{MHz}\right): \delta 201.5$ (s).

Synthesis of $\mathrm{Pd}\left[N\left(2,6-i \mathrm{Pr}_{2} \mathrm{C}_{6} \mathrm{H}_{3}\right)=\mathrm{C}\left(\left(\mathrm{CH}_{3}\right)_{3} \mathrm{OPiPr}\right)\right] \mathrm{Cl}_{2}$ (11). A thf solution of ligand $3(0.5 \mathrm{mmol})$ prepared in situ as described above was added at $-78^{\circ} \mathrm{C}$ to $143 \mathrm{mg}$ of $\mathrm{PdCl}_{2}(\mathrm{cod})(0.5 \mathrm{mmol})$ suspended in $10 \mathrm{~mL}$ of thf. The reaction mixture was stirred and allowed to warm to room temperature over $30 \mathrm{~min}$. The solvent was evaporated under reduced pressure, affording a yellow solid that was extracted with $30 \mathrm{~mL}$ of $\mathrm{CH}_{2} \mathrm{Cl}_{2}$. The solution was taken to dryness, and the residue was recrystallized from thf at $-10^{\circ} \mathrm{C}$ to yield compound 11 as a yellow crystalline solid. Yield: 97 \% (0.27 g). Anal. Calcd for $\mathrm{C}_{23} \mathrm{H}_{40} \mathrm{Cl}_{2} \mathrm{NOPPd}$ : C, 49.79; $\mathrm{H}, 7.27 ; \mathrm{N}, 2.52$. Found: C, 49.63; $\mathrm{H}, 7.31 ; \mathrm{N}, 2.58$. IR (Nujol mull): $v(\mathrm{C}=\mathrm{N}) 1647 \mathrm{~cm}^{-1}$. ${ }^{1} \mathrm{H}$ NMR $\left(25^{\circ} \mathrm{C}, \mathrm{CD}_{2} \mathrm{Cl}_{2}, 300 \mathrm{MHz}\right): \delta$ $1.11(\mathrm{~s}, 9 \mathrm{H}, t \mathrm{BuC}(\mathrm{O}) \mathrm{N}), 1.31\left(\mathrm{~d}, 6 \mathrm{H},{ }^{3} \mathrm{~J}_{\mathrm{HH}}=7 \mathrm{~Hz}\right.$, Aryl-CHMeMe), $1.51\left(\mathrm{dd}, 6 \mathrm{H},{ }^{3} \mathrm{~J}_{\mathrm{HH}}=7 \mathrm{~Hz},{ }^{3} \mathrm{~J}_{\mathrm{HP}}=20 \mathrm{~Hz}\right.$, $\mathrm{PCHMeMe}$ ), $1.52\left(\mathrm{~d}, 6 \mathrm{H},{ }^{3} \mathrm{~J}_{\mathrm{HH}}=7 \mathrm{~Hz}\right.$, Aryl-CHMeMe), 1.61 (dd, $\left.6 \mathrm{H},{ }^{3} J_{\mathrm{HH}}=7 \mathrm{~Hz},{ }^{3} \mathrm{JHP}_{\mathrm{HP}}=20 \mathrm{~Hz}, \mathrm{PCHMeMe}\right)$, $2.71\left(\mathrm{~m}, 2 \mathrm{H}, \mathrm{PCHMe}\right.$ ) $, 2.97\left(\mathrm{~h}, 2 \mathrm{H},{ }^{3} \mathrm{~J}_{\mathrm{HH}}=8 \mathrm{~Hz}\right.$, Aryl-CHMe $), 7.10\left(\mathrm{~d}, 2 \mathrm{H},{ }^{3} \mathrm{~J}_{\mathrm{HH}}=8 \mathrm{~Hz}, m-\mathrm{CH}_{\mathrm{ar}}\right), 7.24(\mathrm{t}, 1 \mathrm{H}$, $\left.{ }^{3} \mathrm{~J}_{\mathrm{HH}}=7 \mathrm{~Hz}, p-\mathrm{CH}_{\mathrm{ar}}\right) \cdot{ }^{13} \mathrm{C}\left\{{ }^{1} \mathrm{H}\right\} \mathrm{NMR}\left(25^{\circ} \mathrm{C}, \mathrm{CD}_{2} \mathrm{Cl}_{2}, 75 \mathrm{MHz}\right): \delta 16.3\left(\mathrm{~d},{ }^{2} \mathrm{~J}_{\mathrm{CP}}=2 \mathrm{~Hz}, \mathrm{PCHMeMe}\right), 17.3\left(\mathrm{~d},{ }^{2} \mathrm{~J}_{\mathrm{CP}}\right.$ $=3 \mathrm{~Hz}, \mathrm{PCHMe}_{2}$ ), 23.3 (s, Aryl-CHMeMe), 24.1 (s, Aryl-CHMeMe), 29.1 (s, Aryl-CHMe $_{2}, 29.3$ (s, $\mathrm{Me}_{3} \mathrm{CC}(\mathrm{O}) \mathrm{N}$ ), 30.2 (d, ${ }^{1} \mathrm{~J}_{\mathrm{CP}}=26 \mathrm{~Hz}, \mathrm{PCHMe}$ ), 41.9 (d, $\left.{ }^{1} \mathrm{~J}_{\mathrm{CP}}=4 \mathrm{~Hz}, \mathrm{Me}_{3} \mathrm{CC}(\mathrm{O}) \mathrm{N}\right), 123.4\left(\mathrm{~s}, m-\mathrm{CH}_{\mathrm{ar}}\right), 128.2$ $\left(\mathrm{s}, p-\mathrm{CH}_{\mathrm{ar}}\right), 139.6\left(\mathrm{~s}, \mathrm{~N}-\mathrm{C}_{\mathrm{ar}}\right), 141.2\left(\mathrm{~s}, \mathrm{o}-\mathrm{C}_{\mathrm{ar}}\right), 177.8(\mathrm{~s}, t \mathrm{BuC}(\mathrm{O}) \mathrm{N}) \cdot{ }^{31} \mathrm{P}\left\{{ }^{1} \mathrm{H}\right\} \mathrm{NMR}\left(25^{\circ} \mathrm{C}, \mathrm{CD}_{2} \mathrm{Cl}_{2}, 121 \mathrm{MHz}\right): \delta$ 194.5 (s).

Synthesis of $\mathrm{Pd}\left[N\left(2,6-\mathrm{PPr}_{2} \mathrm{C}_{6} \mathrm{H}_{3}\right)=\mathrm{C}\left(\left(\mathrm{CH}_{3}\right) \mathrm{OPtBu}\right)\right] \mathrm{Cl}_{2}$ (12). $0.9 \mathrm{~mL}(0.5 \mathrm{mmol})$ of a $0.5 \mathrm{M}$ thf solution of ligand 5 was added to $143 \mathrm{mg} \mathrm{PdCl}$ (cod) $(0.5 \mathrm{mmol})$ suspended in $20 \mathrm{~mL}$ of thf. After stirring for $30 \mathrm{~min}$, the solvent was removed under vacuum. The yellow solid thus obtained was washed with $2 \times 10 \mathrm{~mL}$ of hexane and recrystallized from thf to afford compound 12 as a yellow crystalline solid. Yield: $91 \%(0.25 \mathrm{~g})$. Anal. Calcd for $\mathrm{C}_{22} \mathrm{H}_{38} \mathrm{Cl}_{2}$ NOPPd: $\mathrm{C}, 48.86 ; \mathrm{H}, 7.08 ; \mathrm{N}, 2.59$. Found: $\mathrm{C}, 48.81 ; \mathrm{H}, 6.74 ; \mathrm{N}, 2.67$. IR (Nujol mull): $v(\mathrm{C}=\mathrm{N}) 1611 \mathrm{~cm}^{-1} .{ }^{1} \mathrm{H}$ NMR $\left(25^{\circ} \mathrm{C}, \mathrm{CD}_{2} \mathrm{Cl}_{2}, 300 \mathrm{MHz}\right): \delta 1.15\left(\mathrm{~d}, 6 \mathrm{H},{ }^{3} \mathrm{~J}_{\mathrm{HH}}=7 \mathrm{~Hz}\right.$, Aryl-CHMeMe$), 1.38(\mathrm{~d}$, $6 \mathrm{H},{ }^{3} \mathrm{~J}_{\mathrm{HH}}=7 \mathrm{~Hz}$, Aryl-CHMeMe), $\left.1.64\left(\mathrm{~d}, 18 \mathrm{H},{ }^{3} \mathrm{~J}_{\mathrm{HP}}=16 \mathrm{~Hz}, \mathrm{PCMe}\right)_{3}\right), 1.99(\mathrm{~s}, 3 \mathrm{H}, \operatorname{MeC}(\mathrm{O}) \mathrm{N}), 2.99(\mathrm{~m}, 2 \mathrm{H}$, Aryl-CHMe $), 7.19\left(\mathrm{~d}, 2 \mathrm{H},{ }^{3} \mathrm{~J}_{\mathrm{HH}}=8 \mathrm{~Hz}, m-\mathrm{CH}_{\mathrm{ar}}\right), 7.31$ (t, $\left.1 \mathrm{H},{ }^{3} \mathrm{~J}_{\mathrm{HH}}=8 \mathrm{~Hz}, p-\mathrm{CH}_{\mathrm{ar}}\right) \cdot{ }^{13} \mathrm{C}\left\{{ }^{1} \mathrm{H}\right\}$ NMR $\left(25^{\circ} \mathrm{C}\right.$, 
$\mathrm{CD}_{2} \mathrm{Cl}_{2}, 75 \mathrm{MHz}$ ): $\delta 17.2\left(\mathrm{~d},{ }^{3} \mathrm{~J}_{\mathrm{CP}}=4 \mathrm{~Hz}, \mathrm{MeC}(\mathrm{O}) \mathrm{N}\right.$ ), 23.5 (s, Aryl-CHMeMe), 23.6 (s, Aryl-CHMeMe), 27.7 (d, ${ }^{2} J_{\mathrm{CP}}=4 \mathrm{~Hz}, \mathrm{PCMe}_{3}$ ), 29.1 (s, Aryl-CHMe ), 42.5 (d, ${ }^{1} \mathrm{~J}_{\mathrm{CP}}=12 \mathrm{~Hz}, \mathrm{PCMe}_{3}$ ), 124.0 (s, $m-\mathrm{CH}_{\mathrm{ar}}$ ), 128.5 (s, $p-$ $\mathrm{CH}_{\mathrm{ar}}$ ), 139.6 (s, N-C $\left.\mathrm{C}_{\mathrm{ar}}\right), 141.8$ (s, o- $\left.\mathrm{C}_{\mathrm{ar}}\right), 174.2(\mathrm{~s}, \mathrm{MeC}(\mathrm{O}) \mathrm{N}) \cdot{ }^{31} \mathrm{P}\left\{{ }^{1} \mathrm{H}\right\} \mathrm{NMR}\left(25^{\circ} \mathrm{C}, \mathrm{CD}_{2} \mathrm{Cl}_{2}, 121 \mathrm{MHz}\right): \delta 206.8$ (s).

\section{Computational details.}

Geometry optimizations. Guess structures for the square-planar $(S=0)$ and tetrahedral $(S=1)$ structures of complex 7 were obtained with the semiempirical PM3 method implemented in the Spartan 08 software. ${ }^{62}$ The structures were subjected to full optimization with DFT methods with the Gaussian package. ${ }^{63}$ Two series of calculations were carried out using the B3LYP or BP86 functionals. In either case, the metal atom and all atoms directly bound were described with the $6-311 \mathrm{G}^{*}$ basis set, and the $6-31 \mathrm{G}^{*}$ basis was used for the rest. Geometry minima were checked with frequency calculations.

NMR spectral simulation. Spectral simulations of the variable temperature ${ }^{1} \mathrm{H}$ NMR spectra of 7 were carried out with the gNMR program. ${ }^{64}$ Full lineshape analysis was assisted by a least squares optimization of the simulated and experimental spectra. The fluxional process was modeled as an exchange between the diamagnetic complex, containing the spin system observed in the slow limit, and the paramagnetic species, which was described as two independent spin systems, one of them containing the P atom and the other the $\mathrm{H}$ atoms, in order to ensure complete loss of coupling information. Even though the parameters for the paramagnetic species are unknown, for the purpose of the simulation, their precise values are not important and proof values were used to describe a very small equilibrium concentration and very large chemical shifts typical of such substances. The fact that the thermal drift of the average resonances changes very little over the studied temperature range confirms that the concentration of the paramagnetic species is small. In this case, the exchange rate equals the product $k[\mathrm{SP}]$, where $k$ is the rate constant (square planar to tetrahedral) and [SP] is the concentration of the square planar species, which can be approximated to the total concentration of the complex. It was independently checked that different proof values of the paramagnetic chemical shifts had no significant effect on the spectral line shape, provided that these are very large in comparison with the normal diamagnetic shifts of the diamagnetic compound. For a final refinement of the simulation, the equilibrium constant was estimated from the free activation energy, which is not far from the energy difference between the square planar and the tetrahedral species.

Ethylene oligomerization reactions: General procedure. These reactions were carried out in $250 \mathrm{~mL}$ Fischer-Porter glass reactors provided with a septum-capped injection port, an internal thermocouple probe and magnetic stirring. The reactor was previously oven dried. Then, it was degassed in the vacuum line and charged with the prescribed amounts of solvent (toluene) and catalyst, the latter as a standard solution in $\mathrm{CH}_{2} \mathrm{Cl}_{2}\left(4.5 \times 10^{-3} \mathrm{M}\right.$ or $\left.2.25 \times 10^{-4} \mathrm{M}\right)$. It was then immersed in a thermostat water bath and connected to the ethylene line. After purging 3 times with ethylene to remove the original $N_{2}$ atmosphere, the device was allowed to equilibrate at the required temperature and pressure. At this point, a co-catalyst solution (MMAO 1.9 $\mathrm{M}$ in heptane, Akzo-Nobel, or DEAC 0.25 M in toluene) was added. A color change from purple to yellow 
can be noticed. Ethylene was continuously fed into the reactor from a external reservoir with a calibrated volume to maintain the pressure constant in the reactor. The pressure drop in the reservoir was used to monitor the monomer consumption. The experiments were terminated by releasing the pressure and pouring the mixture in a beaker. These were stored in closed containers at $-20^{\circ} \mathrm{C}$ until GC analyses were performed. Quantitative GC analyses were made using the $\mathrm{CH}_{2} \mathrm{Cl}_{2}$ peak as internal standard. The reaction mixtures were only slightly hazy, and upon treatment with acidified methanol did not produce any significant precipitate of polyethylene. Key experiments were repeated to ensure the reproducibility of the data, which was found to be within $10-15 \%$.

X-ray structure analysis for 7, 8, 9, 10, 11 and 12-thf: A summary of crystallographic data and structure refinement results for these new crystalline compounds are given in Table 5. Crystals coated with dry perfluoropolyether were mounted on glass fibers and fixed in a cold nitrogen stream. Intensity data were collected on a Bruker-AXS Apex CCD diffractometer (7 and 10) or on a Bruker-Nonius X8Kappa Apex II CCD diffractometer $\left(\mathbf{8}, \mathbf{9}, 11\right.$ and $\mathbf{1 2} \cdot \mathbf{0 . 5}$ thf), operating both with graphite monochromated Mo- $\mathrm{K}_{\alpha}$ radiation $(\lambda$ $=0.71073 \AA$ ). The data were reduced by SAINT ${ }^{65}$ and corrected for absorption effects by the multi-scan method (SADABS). ${ }^{65}$ The structures were solved by direct methods (SIR-2002, SHELXS) ${ }^{66,67}$ and refined against all $F^{2}$ data by full-matrix least-squares techniques (SHELXTL-6.12) ${ }^{65}$ minimizing $w\left[F_{\mathrm{o}}^{2}-F_{\mathrm{c}}^{2}\right]^{2}$. All nonhydrogen atoms were refined with anisotropic thermal parameters. Hydrogen atoms were included in calculated positions and allowed to ride on the attached carbon atoms with the isotropic temperature factors $\left(U_{\text {iso }}\right.$ values) fixed at 1.2 times those $U$ eq values of the corresponding carbon atoms (1.5 times for the methyl groups).

Table 5. Summary of crystallographic data and structure refinement results for $\mathbf{7 - 1 2 .}$

\begin{tabular}{|c|c|c|c|c|c|c|}
\hline Compound & 7 & 8 & 9 & 10 & 11 & $12 \cdot 0.5$ thf \\
\hline Chemical formula & $\mathrm{C}_{20} \mathrm{H}_{34} \mathrm{Br}_{2} \mathrm{NNiOP}$ & $\mathrm{C}_{23} \mathrm{H}_{40} \mathrm{Br}_{2} \mathrm{NNiOP}$ & ${ }_{22} \mathrm{H}_{38} \mathrm{Br}_{2} \mathrm{NNiO}$ & ${ }_{20} \mathrm{H}_{34} \mathrm{Cl}_{2} \mathrm{NOPF}$ & $\mathrm{C}_{23} \mathrm{H}_{40} \mathrm{Cl}_{2} \mathrm{NOPJ}$ & $\begin{array}{c}\mathrm{C}_{22} \mathrm{H}_{38} \mathrm{Cl}_{2} \mathrm{NOPPd} \\
\cdot 0.5\left(\mathrm{C}_{4} \mathrm{H}_{8} \mathrm{O}\right)\end{array}$ \\
\hline Formula Mass & 553.98 & 596.06 & 582.03 & 512.75 & 554.83 & 1153.71 \\
\hline Crystal system & Monoclinic & Orthorhombic & Monoclinic & Monoclinic & Orthorhombic & Triclinic \\
\hline$a / \AA$ & $10.7905(7)$ & $15.7309(13)$ & $11.2189(9)$ & $10.884(2)$ & $17.5777(5)$ & $9.8987(14)$ \\
\hline$b / \AA$ & $14.5510(9)$ & $11.6766(7)$ & $14.3721(12)$ & $14.625(3)$ & $10.4053(3)$ & $14.667(2)$ \\
\hline$c / \AA ̊$ & $15.0980(9)$ & $14.6596(10)$ & $15.8988(11)$ & $17.988(4)$ & $14.3919(4)$ & $20.625(3)$ \\
\hline$\alpha /^{\circ}$ & 90.00 & 90.00 & 90.00 & 90.00 & 90.00 & $69.682(4)$ \\
\hline$\beta /^{\circ}$ & $94.0900(10)$ & 90.00 & $95.171(2)$ & $122.881(3)$ & 90.00 & $88.388(5)$ \\
\hline$\gamma /{ }^{\circ}$ & 90.00 & 90.00 & 90.00 & 90.00 & 90.00 & $77.260(4)$ \\
\hline Unit cell volume $/ \AA^{3}$ & $2364.5(3)$ & $2692.7(3)$ & 2553.1(3) & $2404.5(8)$ & $2632.30(13)$ & $2735.1(7)$ \\
\hline Temperature/K & $100(2)$ & $173(2)$ & $173(2)$ & $298(2)$ & $100(2)$ & $100(2)$ \\
\hline Space group & $P 2{ }_{1} / n$ & $\operatorname{Pna}_{1}$ & $P 2_{1} / n$ & $P 2{ }_{1} / c$ & $\operatorname{Pna2}_{1}$ & $P \overline{1}$ \\
\hline No. of formula units per unit cell, $Z$ & 4 & 4 & 4 & 4 & 4 & 2 \\
\hline Radiation type & $\mathrm{MoK}_{\alpha}$ & $\mathrm{MoK}_{\alpha}$ & $\mathrm{MoK}_{\alpha}$ & $\mathrm{MoK}_{\alpha}$ & $\mathrm{MoK}_{\alpha}$ & $\mathrm{MoK}_{\alpha}$ \\
\hline Absorption coefficient, $\mu / \mathrm{mm}^{-1}$ & 4.277 & 3.761 & 3.965 & 1.070 & 0.983 & 0.950 \\
\hline No. of reflections measured & 15298 & 30958 & 49005 & 20505 & 19357 & 42159 \\
\hline No. of independent reflections & 5987 & 4231 & 7573 & 4160 & 7174 & 16583 \\
\hline$R_{\text {int }}$ & 0.0289 & 0.0600 & 0.0445 & 0.0275 & 0.0173 & 0.0270 \\
\hline Final $R_{l}^{[\mathrm{a}]}$ values $\left[F^{2}>2 \sigma\left(F^{2}\right)\right]$ & 0.0347 & 0.0562 & 0.0636 & 0.0231 & 0.0145 & 0.0253 \\
\hline Final $w R\left(F^{2}\right)^{[\mathrm{b}]}$ values $\left[F^{2}>2 \sigma\left(F^{2}\right)\right]$ & 0.0901 & 0.1420 & 0.1607 & 0.0615 & 0.0368 & 0.0673 \\
\hline Final $R_{I}^{[\mathrm{a}]}$ values (all data) & 0.0476 & 0.0692 & 0.0755 & 0.0266 & 0.0154 & 0.0319 \\
\hline Final $w R\left(F^{2}\right)^{[\mathrm{b}]}$ values (all data) & 0.0931 & 0.1503 & 0.1725 & 0.0628 & 0.0373 & 0.0692 \\
\hline Goodness of fit on $F^{2}, \mathrm{~S}^{[\mathrm{c}]}$ & 0.987 & 1.144 & 1.061 & 1.042 & 1.045 & 1.080 \\
\hline
\end{tabular}

a) $R_{l}(F)=\sum(|\mathrm{Fo}|-|\mathrm{Fc}|) / \sum|\mathrm{Fo}|$. b) $w R_{2}\left(F^{2}\right)=\left\{\sum\left[w\left(F_{\mathrm{o}}{ }^{2}-F_{\mathrm{c}}{ }^{2}\right)^{2}\right] / \sum w\left(F_{\mathrm{o}}{ }^{2}\right)^{2}\right\}^{1 / 2}$. c) $S=\left\{\sum\left[w\left(F_{\mathrm{o}}^{2}-F_{\mathrm{c}}{ }^{2}\right]^{2} /(\mathrm{n}-\mathrm{p})\right\}^{1 / 2} ;(\mathrm{n}=\right.$ number of reflections, p $=$ number of parameters).

\section{Acknowledgement}


Financial support from the DGI (Project CTQ2009-11721), Junta de Andalucía (Project P09FQM5074) and EU (FEDER Funds) is gratefully acknowledged. I. M. thanks a a postdoctoral contracts from the Junta de Andalucía.

\section{References.}

(1) a) Braunstein, P. Chem. Rev. 2006, 106, 134. b) Braunstein, P.; Naud, F. Angew. Chem. Int. Ed. 2001, 40, 680.

(2) a) Nakamura, A.; Ito, S.; Nozaki, K. Chem. Rev., 2009, 109, 215. b) Berkfield, A.; Mecking, S. Angew. Chem. Int. Ed. 2008, 47, 2538.

(3) a) Liang, L.-C. Coord. Chem. Rev. 2006, 250, 1152. b)Maggini, S. Coord. Chem. Rev. 2009, 253, 1793. c) van der Vlugt, J. I.; Reek, J. N. H. Angew. Chem. Int. Ed. 2009, 48, 8832.

(4) Helmchen, G.; Pfaltz, A. Acc. Chem. Res. 2000, 33, 336.

(5) McManus, H. A.; Guiry, P. J. Chem. Rev. 2004, 104, 4151.

(6) Guironnet, D.; Caporaso, L.; Neuwald, B.; Göttker-Schnetmann, I.; Cavallo, L.; Mecking, S. J. Am. Chem. Soc. 2010, 132, 4418.

(7) a) Haras, A.; Michalak, A.; Rieger, B.; Ziegler, T. J. Am. Chem. Soc. 2008, 127, 8765. b) Noda, S.; Nakamura, A.; Kochi, T.; Chung, L. W.; Morokuma, K.; Nozaki, K. J. Am. Chem. Soc. 2009, 121, 14088.

(8) Speiser, F.; Braunstein, P.; Saussine, L. Acc. Chem. Res. 2005, 38, 784.

(9) Younkin, T. R.; Connor, E. F.; Henderson, J. I.; Friedrich, S. K.; Grubbs, R. H.; Bansleben, D. A. Science 2000, 287, 460.

(10) Kermagoret, A.; Braunstein, P. Organometallics 2008, 27, 88.

(11) Vogt, D. Applied Homogeneous Catalysis with Organometallic Compounds; Cornils, B.; Herrmann, W. A.; Eds., Wiley-VCH: Weinheim 2002, 1, 245.

(12) Ravasio, A.; Boggioni, L.; Tritto, I. in Olefin Upgrading Catalysis by Nitrogen-based Metal Complexes, G. Gianbastiani and J. Cámpora, Eds. Springer, Dordrecht: 2011.

(13) Skupinska, J. Chem. Rev. 1991, 91, 613.

(14) Keim, W. Angew. Chem. Int. 1990, 29, 235.

(15) Keim, W. New J. Chem. 1994, 18.

(16) Kuhn, P.; Semeril, D.; Matt, D.; Chetcuti, M. J.; Lutz, P. Dalton Trans. 2007, 515.

(17) Soula, R.; Broyer, J. P.; Llauro, M. F.; Tomov, A.; Spitz, R.; Claverie, J.; Drujon, X.; Malinge, J.; Saudemont, T. Macromolecules 2001, 34, 2438.

(18) Thapa, I.; Gambarotta, S.; Korobkov, I.; Duchateau, R.; Kulangara, S. V.; Chevalier, R. Organometallics 2010, 29, 4080.

(19) Forestière, A.; Olivier-Bourbigou, H.; Saussine, L. Oil Gas Sci. Technol. 2009, 64, 649.

(20) Guo, C.-Y.; Peulecke, N.; Basvani, K. R.; Kindermann, M. K.; Heinicke, J. Macromolecules 2010, 43, 1416.

(21) Chavez, P.; Rios, I. G.; Kermagoret, A.; Pattacini, R.; Meli, A.; Bianchini, C.; Giambastiani, G.; Braunstein, P. Organometallics 2009, 28, 1776.

(22) Flapper, J.; Kooijman, H.; Lutz, M.; Spek, A. L.; van Leeuwen, P.; Elsevier, C. J.; Kamer, P. C. J. Organometallics 2009, 28, 3272.

(23) Speiser, F.; Braunstein, P.; Saussine, L. Organometallics 2004, 23, 2625. 
(24) Speiser, F.; Braunstein, P.; Saussine, L. Organometallics 2004, 23, 2633.

(25) Speiser, F.; Braunstein, P.; Saussine, L.; Welter, R. Organometallics 2004, 23, 2613.

(26) Speiser, F.; Braunstein, P.; Saussine, L.; Welter, R. Inorg. Chem. 2004, 43, 1649.

(27) Guan, Z.; Marshall, W. J. Organometallics 2002, 21, 3580.

(28) Chen, H.-P.; Liu, Y.-H.; Peng, S.-M.; Liu, S.-T. Organometallics 2003, 22, 4893.

(29) Daugulis, O.; Brookhart, M.; White, P. S. Organometallics 2002, 21, 5935.

(30) Flapper, J.; van Leeuwen, P. W. N. M.; Elsevier, C. J.; Kamer, P. C. J. Organometallics 2009, 28, 3264.

(31) van den Beuken, E. K. S., W. J. J.; Spek, A. L.; Feringa, B. L. Chem. Commun. 1998, 223.

(32) Keim, W.; Killat, S.; Nobile, C. F.; Suranna, G. P.; Englert, U.; Wang, R.; Mecking, S.; Schröder, D. L. J. Organomet. Chem. 2002, 662, 150.

(33) Killian, C. M.; McDevitt, J. P.; Mackenzie, P. B.; Moody, L. S.; Ponasik, J. A., Jr. WO 98404201998.

(34) Buchard, A.; Auffrant, A.; Klemps, C.; Vu-Do, L.; Boubekeur, L.; Goff, X. F. L.; Floch, P. L. Chem. Commun. 2007, 1502.

(35) Daugulis, O.; Brookhart, M. Organometallics 2002, 21, 5926.

(36) Johnson, L. K.; Killian, C. M.; Brookhart, M. J. Am. Chem. Soc. 1995, 117, 6414.

(37) Gates, D. P.; Svejda, S. A.; Oñate, E.; Killian, C. M.; Johnson, L. K.; White, P. S.; Brookhart, M. Macromolecules 2000, 33, 2320.

(38) Ittel, S. D.; Johnson, L. K.; Brookhart, M. Chem. Rev. 2000, 100, 1169.

(39) Tempel, D. J.; Johnson, L. K.; Huff, R. L.; White, P. S.; Brookhart, M. J. Am. Chem. Soc. 2000, 122, 6686.

(40) Guan, Z.; Popeney, C. S. in Metal Catalysts in Olefin Polymerization. Z. Guan, Ed. Springer, Berlin: 2009.

(41) Speiser, F.; Braunstein, P.; Saussine, L. Dalton Trans. 2004, 1539.

(42) Kühl, O. Coord. Chem. Rev. 2006, 250, 2867.

(43) Slawin, A. M. Z.; Wainwright, M.; Woollins, J. D. J. Chem. Soc., Dalton Trans. 2001, 2724.

(44) Ly, T. Q.; Slawin, A. M. Z.; Woollins, J. D. Angew. Chem. Int. Ed. 1998, 37, 2501.

(45) Braunstein, P.; Frison, C.; Morise, X.; Adams, R. D. J. Chem. Soc., Dalton Trans. 2000, 2205.

(46) Rodriguez i Zubiri, M.; Milton, H. L.; Slawin, A. M. Z.; Woollins, J. D. Polyhedron 2004, 23, 865.

(47) Bhattacharyya, P.; Ly, T. Q.; Slawin, A. M. Z.; Woollins, J. D. Polyhedron 2001, 20, 1803.

(48) Agostinho, M.; Rosa, V.; Aviles, T.; Welter, R.; Braunstein, P. Dalton Trans. 2009, 814.

(49) Jones, N. G.; Green, M. L. H.; Vei, I.; Cowley, A.; Morise, X.; Braunstein, P. J. Chem. Soc., Dalton Trans. 2002, 1487.

(50) Hosokawa, T. W., Y.; Hosokawa, K.; Tsuji, T.; Murahashi, S. I. J. Chem. Soc., Chem. Commun. 1996, 859.

(51) Braunstein, P.; Heaton, B. T.; Jacob, C.; Manzi, L.; Morise, X. Dalton Trans. 2003, 1396.

(52) Roucoux, A.; Thieffry, L.; Carpentier, J.-F.; Devocelle, M.; Meliet, C.; Agbossou, F.; Mortreux, A.; Welch, A. J. Organometallics 1996, 15, 2440.

(53) Harvey, J. N. Ann. Rep. Prog. Chem., Sect. C, 2006, 102, 203.

(54) Svejda, S. A.; Johnson, L. K.; Brookhart, M. J. Am. Chem. Soc. 1999, 121, 10634.

(55) Tempel, D. J.; Johnson L. K.; Huff, R. L.; White, P. S. Brookhart, M. J. Am. Chem. Soc. 2000, 122, 6686.

(56) Shultz, L. H.; Tempel, D. J.; Brookhart. M. J. Am. Chem. Soc., 2001, 123, 11539. 
(57) Leatherman, M. D.; Svejda, S. A.; Johnson, L. K.; Brookhart, M. J. Am. Chem. Soc. 2003, 125, 3068.

(58) Killian, C. M.; Johnson, L. K.; Brookhart, M. Organometallics 1997, 16, 2005.

(59) Ward, L. G. L.; Pipal, J. R. Inorg. Synth., 1971, 13, 154.

(60) Drew, D.; Doyle, J. R. Inorg. Synth., 1971, 13, 47.

(61) Boeré, R. T. K., V.; Wolmershäusser, G. J. Chem. Soc., Dalton Trans. 1998, 4147.

(62) Spartan 08, Wavefunction, Inc. Irvine, CA.

(63) Frisch, M. J.; et al. Gaussian 03, Revision B.04; Gaussian, Inc.: Pittsburg, 2003.

(64) gNMR 3.6 for Macintosh. Cherwell Scientific Publishing Ltd. Oxford .

(65) Bruker programs: SMART, version 5.629; SAINT+, version 6.45; SADABS, version 2.10; SHELXTL, version 6.12; Bruker AXS Inc.: Madison, WI, 2003.

(66) Burla, M. C.; Camalli, M.; Carrozzini, B.; Cascarano, G. L.; Giacovazzo, C.; Polidori, G. Spagna, R. SIR2002: the program; J. Appl. Cryst, 2003, 36, 1103.

(67) Sheldrick, G. M. SHELX97: Program System for Crystal Structure Determination; University of Göttingen, Göttingen, Germany, WI, 1997. 


\section{For Table of Contents Only:}

A series of phosphinito-imine ligands and their nickel and palladium complexes $M(P-N) X_{2}$ has been synthesized. On treatment with MMAO or DEAC, the nickel derivatives give rise to highly active ethylene oligomerization catalysts.
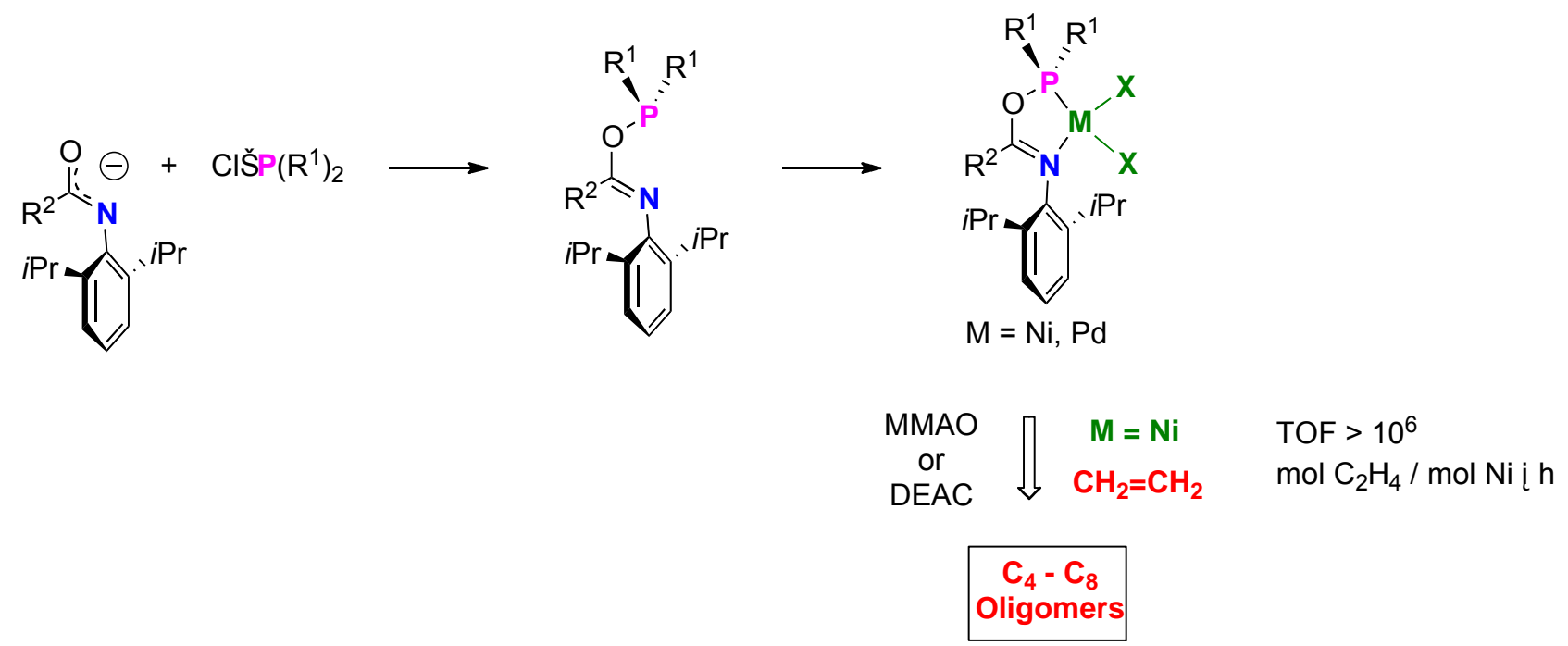